\title{
HYDRAULIC FRACTURING IN THE EUROPEAN UNION: LEVERAGING THE U.S. EXPERIENCE IN SHALE GAS EXPLORATION AND PRODUCTION
}

\author{
Joanna Glowacki ${ }^{1}$ and Christoph Henkel ${ }^{2}$
}

\section{INTRODUCTION}

Hydraulic fracturing has been the subject of much debate recently, both in the United States ${ }^{3}$ and increasingly in Europe. ${ }^{4}$ Advances in hydraulic fracturing technology have led to a shale gas boom in the United States, significantly lowering natural gas prices, ${ }^{5}$ and causing some foreign businesses to move manufacturing plants from Europe to the United States. ${ }^{6}$ In the United States, approximately 11,000 new wells are "fracked" each year, adding to the currently existing 35,000 wells. $^{7}$ When compared to

1. Associate Regional Counsel, U.S. EPA, Region 5, University of Wisconsin, B.A., J.D. Ms. Glowacki is an expert in the Safe Drinking Water Act and Federal Insecticide, Fungicide, and Rodenticide Act. Any opinion expressed herein is that of the author and does not necessarily represent the views of the Agency. This work is not a product of the United States Government or the United States Environmental Protection Agency, and the author is not doing this work in any governmental capacity. The author would like to thank Robert Thompson for providing his expertise in the Clean Water Act and his review of this Article.

2. Associate Professor of Law, Mississippi College School of Law. Assessor iuris, University of Wisconsin, LL.M., S.J.D. Professor Henkel is the Co-Director of the International and Comparative Law Center at the Mississippi College School of Law and teaches Domestic and International Commercial Law, Bankruptcy, and European Union Law. The author would like to acknowledge the support provided by Mississippi College School of Law on this project and thank Ms. Stephanie Naylor for her outstanding research assistance.

3. See, e.g., Jon Entine, Will Washington Politics Kill the U.S. Energy Revival and Shale Gas Revolution?, FORBES (Aug. 22, 2013, archived at http://perma.cc/E5LS-NLLW); Sylvia Pfeifer and Pilita Clark, Critics Try to Stifle Shale Gas Revolution, Fin. TiMEs (May 12,2011 ), available at $\mathrm{http} / / \mathrm{www} . \mathrm{ft} . \mathrm{com} / \mathrm{int} / \mathrm{cms} / \mathrm{s} / 0 / \mathrm{b} 381 \mathrm{~d} 7 \mathrm{ca}-7 \mathrm{c} 24-11 \mathrm{e} 0-\mathrm{a} 386$

00144feabdc0.html\#axzz2gCTdbRux); Michael Wines, Gas Leaks in Fracking Disputed in Study, N.Y. TimES (Sept. 16, 2013, archived at http://perma.cc/5PFC-CR5D).

4. See, e.g., Report on the ENVIRONMENTAL IMPACts OF Shale Gas and Shale OIL Extraction ACtivities, Eur. Parl. DOC. (A7-0283) (2012) [hereinafter IMPACTS OF SHALE GAS].

5. Ed Crooks, et al., U.S. Energy Revolution Gathers Pace, FIN. TIMEs, May 17, 2013.

6. Chris Bryant, High European Energy Prices Drive BMW to U.S., FIN. Times (May 27, 2013), available athttp://www.ft.com/intl/cms/s/0/be69a732-ab5a-1 le2-8c63-

00144 feabdc0.html\#axzz2cTcXQbrN (quoting a managing director of the joint venture between BMW and the SGL Group in the US: "The main reason for wanting to be based [in the United States] was to secure an adequate supply of energy from renewable sources. But another decisive factor was the low energy price." (alteration added)).

7. Oil and Natural Gas Air Pollution Standards, EPA, http://www.epa.gov/airquality/ oilandgas/ (last updated Sep. 4, 2013, archived at http://perma.cc/Q3EZ-YVVJ); see, e.g., EPA, EPA/600/D-11/001, Draft Plan to Study the Potential Impacts of Hydraulic 
these numbers, European shale gas exploration remains in its infancy and commercial scale gas extraction has yet to be established. ${ }^{8}$ At the same time, many Member States in the European Union consider the exploration of unconventional fossil fuels essential for their energy security and independence from Russian gas. ${ }^{9}$ Indeed, Europe may hold some of the largest technically recoverable shale gas resources, not far behind the US, China, Argentina, and Mexico. ${ }^{10}$

While natural gas is a cleaner burning fossil fuel than oil, ${ }^{11}$ the fracking process itself, ${ }^{12}$ as well as its requisite infrastructure, brings with it numerous environmental and health concerns. ${ }^{13}$ As shale gas exploration progresses further and is commercially developed, many previously unrecognized and underestimated concerns have become more prevalent. ${ }^{14}$ The use of fresh water during the process of fracturing and the potential for pollution of surface and groundwater are only two examples of such

Fracturing ON DRINKING WATER ReSOURCES 19 (2011); see also, Ian Urbina, Regulation Lax As Gas Wells' Tainted Water Hits Rivers, N.Y. TIMES (Feb. 26, 2011, archived at http://perma.cc/PW38-KXT9).

8. See Philippe \& Partners, Final Report on Unconventional Gas in Europe 5 (2011), archived at http://perma.cc/U6C4-H5FP; DIRECTORATE GENERAL FOR INTERNAL Policies, IMPACTS OF SHALE GaS aNd SHALE OIL EXTRACTION ON THE ENVIRONMENT AND ON HUMAN HEALTH 12 (2011), archived at $\mathrm{http}: / /$ perma.cc/5VA9-7AF7.

9. Michael RatNer, et. al, Cong. Research SeRV., Europe's ENERGy Security: OPTIONS AND CHALLENGES TO NATURAL GAS SUPPLY DIVERSIFICATION 18 (2013), archived at http://perma.cc/REY6-DUKE; JOINT RESEARCH CTR. SCIENTIFIC AND POLICY REPORTS, UnCONVENTIONAL Gas: Potential ENERGY MaRKET IMPACTS IN THE EUROPEAN UNION, archived at http://perma.cc/DP7J-PF23; Ladka Bauerova, Chevron Draw Europe Towards Natural Gas Independence: Energy, Bloomberg (July 24, 2013, archived at http://perma.cc/HM75-KG9E).

10. See generally U.S. Energy Info. Admin., Technically Recoverable Shale OIL and Shale Gas Resources: AN Assessment of 137 Shale Formations in 41 Countries OUTSIDE THE UNITED STATES, ch. VIII-XIII (2013).

11. What is Shale Gas and Why is it Important?, infra note 34; see also Guy Chazan, Fuel Rises to Challenge Oil Industry's Supremacy, FIN. TIMEs, Apr. 16, 2013.

12. Hydraulic fracturing, or fracking, is an extraction method used to obtain oil or gas that is trapped in tight rock formations, such as shale. The method involves the high-pressure injection of fracturing fluids into shale formations and fractures the rock that traps the gas. See Directorate General for InTERnal Policies, supra note 8, at 12-16; see also PHILIPPE \& PARTNERS, supra note 8, at 7-8.

13. See, e.g., Michelle Bamberger \& Robert E. Oswald, Impacts of Gas Drilling on Human and Animal Health, 22 NEw SOLUTIONS 51 (2012) archived at http://perma.cc/JPL3T5NE; Stephen G. Osborn, et al., Methane Contamination of Drinking Water Accompanying Gas Well Drilling and Hydraulic Fracturing, 108 PNAS 8172 (2011); AEA, REPORT FOR THE EUROPEAN COMMISSION, SUPPORT TO THE IDENTIFICATION OF POTENTIAL RISKS FOR THE ENVIRONMENT AND HUMAN HEALTH ARISING FROM HYDROCARBONS OPERATIONS INVOLVING FRACTURING IN EUROPE iii-xvi (2012), archived at http://perma.cc/733G-6QGQ [hereinafter AEA REPORT POTENTIAL RISKS].

14. Directorate General for Internal Policies, Impacts of Shale Gas and Shale OIL EXTRACTION ON THE ENVIRONMENT AND ON HUMAN HEALTH 17-19 (2011), archived at http://perma.cc/5VA9-7AF7 at 17-19. 
concerns. ${ }^{15}$ In fact, a clear picture of the types and quantities of chemicals being used as additives in fracking fluids injected into the ground and the risks they may pose for the environment or human health has been lacking. ${ }^{16}$ In the United States, under the Safe Drinking Water Act, a permit is required only if diesel fuels are used as additives in fracking fluids. ${ }^{17}$ Yet, there is no definite clarity with respect to whether operators are actually using diesel fuels as additives or how much is being used. ${ }^{18}$

With more shale gas wells drilled than ever before, there are increasing reports of contaminated drinking water wells, concerns about water acquisition and questions about how to treat fracking wastewaters. ${ }^{19}$ Add to that the fact that the oil and gas industry enjoys numerous exemptions under many of the US environmental statute ${ }^{20}$ and it becomes clear why the development of shale gas is controversial. ${ }^{21}$ In response, many countries and state governments have implemented bans or moratoria on the use of hydraulic fracturing in their respective jurisdictions. In Europe, France, and Bulgaria such moratoria have been enacted. ${ }^{22}$ Likewise, in the United States, many states, including North Carolina, ${ }^{23}$ New York, ${ }^{24}$ New Jersey, ${ }^{25}$ and Vermont, ${ }^{26}$ have done the same, banning fracking for the extraction of oil or gas.

With little or no experience in shale gas development, Europe is looking toward the United States as a potential model for its nascent regulatory framework. ${ }^{27}$ While there is a patchwork of EU directives ${ }^{28}$ that address fracturing, there are specific shortcomings due to the fact that shale

15. Id. at $17-19,55$.

16. Id. at $31-34$. The U.S. EPA is currently engaged in a study to look at the effect of fracking on drinking water. See generally infra EPA Study note 62.

17. See, e.g., Suzanne Goldenberg, Fracking Produces Annual Toxic Waste Water Enough to Flood Washington D.C., THE GUARDIAN, Oct. 4, 2013, archived at http://perma.cc/ZFB6-HRKQ.

18. See, e.g., Laura Legere, Details Few on Diesel Used in PA. Fracking, THE TIMESTRIB. (Feb. 2, 2011, archived at http://perma.cc/CP72-S86L).

19. See infra Part II.B.

20. See, e.g., AbBi L. Cohen \& John M. Ix, What's the Deal With Fracking? REGULATION, LITIGATION, AND DUE DILIGENCE 4, archived at http://perma.cc/G2BD-KR6N.

21. See, e.g., Mark Riley Cardwell \& Josh Fox, Anti-Fracking Protests Could Stop Drilling in the UK, THE GUARDIAN (Oct. 29, 2013, archived at http://perma.cc/A7XGUWEU).

22. See IMPACTS OF SHALE GAS, supra note 4, at 6.

23. See S.B. 820, Gen. Assemb. (N.C. 2011), archived at http://perma.cc/MQK2-PZ77.

24. See S.B. 4276, Gen. Assemb., Reg. Sess. (N.Y. 2013), archived at http://perma.cc/5R8Z-VNT7; see also Michael Virtanin, N.Y.'s Highest Court to Hear AntiFracking Case, USA TODAY (Aug. 29, 2013, archived at http://perma.cc/TA7H-MAEP).

25. See S.B. 3644, 215th Leg. (N.J. 2013), archived at http://perma.cc/74LR-Z4N5.

26. See H.B. 464, 2012 Leg. (Vt. 2012), archived at http://perma.cc/F6VD-Q6HY.

27. See infra note 289 at 8,79 and accompanying text.

28. See infra Part V. 
gas development has not been pursued in Europe. The European Commission and the European Parliament continue to evaluate the impact of fracturing on the environment and human health, and have already released numerous studies and reports. ${ }^{29}$ It is the objective of these initiatives to ensure that the environmental risks arising from shale gas projects and cumulative developments are adequately identified and managed in Europe ${ }^{30}$ In addition, the European Union is attempting to establish a common regulatory approach allowing for a comparable and coherent regulatory environment across the European Union and all its Member States. ${ }^{31}$

This Article analyzes the existing regulatory frameworks in the United States and European Union as they relate to hydraulic fracturing of shale gas. It is argued that while the United States' experience may serve as an example for the European Union, the shale gas boom in the United States has raised a host of environmental and health concerns that need to be addressed. At the same time, the United States may be well advised to consider some of the developments in Europe, where, for example, mutual non-disclosure agreements regarding damages to the environment and human health may not be allowed. ${ }^{32}$

First, this Article briefly discusses the methods of hydraulic fracturing and the major environmental concerns associated with the exploration of shale gas. Part two reviews the regulatory approach of hydraulic fracturing in the United States and discusses new developments in the existing legal framework. The third and final part of the Article focuses on developments in the European Union. The legislative powers of the European Union in the areas of environmental protection and energy policy are considered first, followed by a brief discussion of the most relevant norms that apply to fracturing in Europe. As shortcomings are identified, current developments

29. See, e.g., MARK BROOMFIELD, AEA, SUPPORT TO THE IDENTIFICATION OF POTENTIAL RISKS FOR THE ENVIRONMENT AND HUMAN HEALTH ARISING FROM HYDROCARBONS OPERATIONS INVOLVING HYDRAULIC FRACTURING IN EUROPE (2012), archived at http://perma.cc/B88A-NTDG; DanIEl Forster \& Jonathan Perks, Climate IMPaCt of Potential Shale Gas Production IN THE EU (2012), archived at http://perma.cc/8E4BhHgS; Ivan Pearson, et al., Unconventional Gas: Potential Energy Market IMPACTS IN THE EUROPEAN UNION (2012) [hereinafter JRC RESEARCH STUDY], archived at http://perma.cc/H8SP-27T7.

30. PhILIPPE \& PARTNERS, supra note 8, at 5-6; see also JRC RESEARCH STUDY, supra note 29 , at iii-iv.

31. See, e.g., Press Release, European Parliament, Statement by Commissioner Potoxnik Following the Vote in the European Parliament on Shale Gas (Nov. 21, 2012, archived at http://perma.cc/3SPB-N4XM)("Studies carried out indicate that there are a number of uncertainties or gaps in current EU legislation and the Commission intends to deliver next year a framework to manage risks, address regulatory shortcomings, and to provide maximum clarity and predictability to market operators and citizens across the EU.").

32. See IMPACTS OF SHALE GAS, supra note 4, at 8, 117. 
and initiatives by the European Commission and Parliament to address these shortcomings are described.

\section{THE SHALE GAS REVOLUTION}

\section{A. Shale Gas and Hydraulic Fracturing in the United States}

\section{Shale Gas Development}

Natural gas has a substantial role in the United States' use of energy. Resources are abundant, and natural gas is commonly lauded not only for its clean-burning nature and economic viability, but also for its reliability and popularity in a wide range of industries. ${ }^{33}$ Whereas conventional gas reservoirs are created when gas migrates from an organic-rich source formation into a permeable reservoir rock trapped by an overlying layer of impermeable rock, shale gas resources form within the organic-rich shale source rock. $^{34}$ The result is that such formations have limited horizontal permeability and extremely limited vertical permeability. ${ }^{35}$ Unlike conventional reservoirs that contain gas in interconnected pore spaces that can easily flow to a wellbore, ${ }^{36}$ unconventional reservoirs, or shale gas formations with low permeability, trap gas within the reservoir rock itself. ${ }^{37}$ To create additional permeability, it is necessary to stimulate the reservoir. ${ }^{38}$ This is accomplished through hydraulic fracturing. Historically, shale or sedimentary rock formations have produced small amounts of natural gas, ${ }^{39}$ thereby limiting their economic viability. ${ }^{40}$ However, advances in hydraulic fracturing technologies and increased use of horizontal drilling ${ }^{41}$ have been

33. U.S. DEP'T OF ENERgy, Modern Shale Gas DeVelopment in the UNited States: A PRIMER 3-4 (2009) [hereinafter PRIMER], archived at http://perma.cc/PA9V-G3KA; natural gas is a major fuel source for pulp and paper, metals, chemicals, petroleum refining and food processing. Id. at 4.

34. What is Shale Gas and Why is it Important?, U.S. ENERGY INFORMATION ADMIN., http://www.eia.gov/energy_in_brief/article/about_shale_gas.cfm (last updated Dec. 5, 2012, archived at http://perma.cc/6BNL-ALER).

35. PRIMER, supra note 33, at 14.

36. PRIMER, supra note 33 , at 15 .

37. PRIMER, supra note 33, at 15.

38. PRIMER, supra note 33, at 15 .

39. See U.S. Dep'T of Energy, Shale Gas: Applying Technology to Solve AMERICA's ENERGY CHALLENGES 3 (2011), archived at http://perma.cc/XC99-EM7M.

40. PRIMER, supra note 33, at 13.

41. PRIMER, supra note 33, at 13; horizontal drilling dates back to the $1930 \mathrm{~s}-40$ s. Advances in horizontal drilling could be seen as a tipping point in the fracking process. Because shale formations have low permeability, particularly vertically, vertical wells must be spaced in closer intervals. Horizontal wells provide more exposure over a larger area. As a result, six to eight horizontal wells over a one square mile area could tap into the same or 
a turning point for shale gas production in the United States. Shale plays ${ }^{42}$ once considered to be lacking potential for production and profit are being re-examined. ${ }^{43}$ Demand and production of natural gas has increased, ${ }^{44}$ and current estimates indicate that most of this increase is due to projected growth in shale gas production. ${ }^{45}$

\section{The Hydraulic Fracturing Process}

Commonly thought of as a drilling process, hydraulic fracturing, or "fracking," is actually a well stimulation process used to maximize the extraction of underground resources such as natural gas, oil, and geothermal energy. ${ }^{46}$ The fracking process begins with the building of site infrastructure, which necessarily includes well construction. ${ }^{47}$ Wells are drilled to intersect shale formations at depths that typically range from 6,000 to more than 14,000 feet and horizontal sections that extend 1,000 to 6,000 feet away from the well. ${ }^{48}$ Fluids consisting of water, sand, and chemical additives are injected through the wellbore into the geologic formation under very high pressure. ${ }^{49}$ The process of hydraulic fracturing is comprised of various stages and tailored to the particular needs of a shale formation ${ }^{50}$ as shale basins in the United States are each different, with unique exploration criteria and operational challenges. ${ }^{51}$ For each stage of

larger reservoir volume as sixteen vertical wells each located on a separate well pad in the same sized area. PRIMER, supra note 33, at 46-47.

42. See Glossary, EIA.GOV, http://www.eia.gov/tools/glossary/index.cfm?id=P (last visited Nov. 16, 2013, archived at http://perma.cc/8VMH-D9HF)(Defining a play as "A set of known or postulated oil and gas accumulations sharing similar geologic, geographic, and temporal properties, such as source rock, migration pathway, timing, trapping mechanism, and hydrocarbon type. ... A play is often used to refer to a natural gas accumulation, i.e., a natural gas shale play.").

43. PRIMER, supra note 33 , at 16.

44. See EPA, Memo from James Hanlon, Director of ePA's Office of Wastewater Management to the EPA Regions, Natural Gas Drilling IN tHE MARCELlus Shale NPDES Program FAQ 1 (2011) [hereinafter EPA FAQ], archived at http://perma.cc/U3GG-PLAA.

45. See, e.g., What is Shale Gas and Why is it Important?, supra note 34; U.S. DEP'T OF ENERGY, supra note 39, at 4.

46. Hydraulic Fracturing Background Information, EPA, http://water.epa.gov/type/ groundwater/uic/class2/hydraulicfracturing/wells_hydrowhat.cfm (last updated May 9, 2012, archived at http://perma.cc/4UBV-WLVZ).

47. Id.

48. Id.; U.S. DEP'T OF ENERGY, supra note 39, at 5.

49. PRIMER, supra note 33 , at 56,61 .

50. Hydraulic Fracturing: The Process, FracFocus Chemical Disclosure RegisTRY, $\mathrm{http}$ //fracfocus.org/hydraulic-fracturing-how-it-works/hydraulic-fracturing-process (last visited Jan. 22, 2014, archived at http://perma.cc/D8Z-7NVJ).

51. Primer, supra note 33, at 16 (for example, the Antrim and New Albany Shales are shallower and produce significant volumes of formation water as opposed to other gas shales in the country). 
treatment, called sub-stages, a series of different volumes of fracture fluids with specific additives and proppant concentrations is injected sequentially. ${ }^{52}$ These additives serve various purposes. For example, depending on the conditions of the shale basin, the first sub-stage might be an "acid stage," where several thousand gallons of water mixed with a dilute acid works to clear cement debris and provide an open conduit for other fluids. ${ }^{53}$ The next stage might be a "pad stage," consisting of roughly 100,000 gallons of slickwater which fills the wellbore with a solution that facilitates flow and placement of proppant material. ${ }^{54}$ Additionally, biocides act to prevent microorganism growth and oxygen scavengers are used to prevent corrosion of metal pipes. 55

Once the pressure exceeds the rock strength, the fluids open or enlarge fractures in the rock. ${ }^{56}$ The proppant material "props" or keeps the fractures from closing when the pumping pressure is reduced, thereby allowing the once-trapped gas to travel up the well casing to the wellhead. ${ }^{57}$ After fracturing is completed, the internal pressure of the geologic formation causes the injected fracturing fluids, called flowback, to rise to the surface, along with natural formation waters and other naturally occurring substances. ${ }^{58}$ The flowback may happen over time $e^{59}$ and ultimately requires management of the wastewater through recycling, injection, storage, or treatment, as discussed below.

\section{B. Environmental Concerns of Hydraulic Fracturing}

\section{Water}

Perhaps the most significant environmental concerns with respect to hydraulic fracturing are impacts on water. These impacts affect not only water usage and quality, both for drinking and US waters, but also management and treatment. There is no doubt that fracking necessitates substantial amounts of water; drilling and fracking of a horizontal well may

52. PRIMER, supra note 33 , at 58.

53. Hydraulic Fracturing: The Process, supra note 50.

54. Hydraulic Fracturing: The Process, supra note 50.

55. PRIMER, supra note 33, at 61,63 (charting a list of additives, their main compounds, and purpose).

56. What is Fracking?, HYDRauliC FRACTURING IN THE LeHIGH Valley, http://sites.lafayette.edu/egrs251-fal1-fracking/what-is-hydraulic-fracturing (last visited Jan. 22, 2014, archived at http://perma.cc/N6V-GSY4).

57. Id.; PRIMER, supra note 33, at 66 .

58. Hydraulic Fracturing Background Information, supra note 46; PRIMER, supra note 33 , at $66-67$.

59. The majority of fluid is captured within several hours or weeks. In some cases, however, flowback of fracturing fluid in produced water can continue for several months after gas production has begun. PRIMER, supra note 33, at 66. 
typically require between two to four million gallons of water. ${ }^{60}$ However, some accounts indicate that individual wells have required between 16 and 21 million gallons of water. ${ }^{61}$ When one considers that a single well pad can contain up to eight wells, water volume increases significantly. Moreover, the United States Environmental Protection Agency (EPA) has estimated that each year 35,000 wells are being fracked and that the annual water requirement may range from 70 to 140 billion gallons. ${ }^{62}$ Sources for this sizeable volume of water typically include groundwater, surface water, or treated wastewater. ${ }^{63}$ Accordingly, the larger question is whether such substantial withdrawals of water have the ability to impact sources of drinking water ${ }^{64}$ and water availability for the public in general.

The substantial volume of water used during the fracking process does not remain underground. As noted above, flowback of fluid occurs during the fracturing of a well, resulting in wastewater containing dissolved chemicals and other contaminants that must be managed. ${ }^{65}$ Management of fracking wastewater presents a number of concerns. Operators use storage tanks and pits to temporarily store waste fluids for later use or disposal. ${ }^{66}$ If mismanaged, these fluids can be released through spills or leaks, faulty well construction, or other exposure pathways. ${ }^{67}$

Another option for wastewater management is to dispose of fracking wastewater fluids through injection into deep wells. ${ }^{68}$ Aside from concerns about proper casing and cementing of the well or corrosion that might compromise well integrity, ${ }^{69}$ underground injection is not available for every shale basin in the US, since injection requires a porous and permeable

60. PRIMER, supra note 33, at 64.

61. Michigan's 21 Million Gallon Frack Job: A National Record?, EcoWATCH: Cutting Edge Environmental News Service (Feb. 5, 2013, archived at http://perma.cc/R74L-E74U).

62. Envtl. Prot. Agency, Draft Plan to Study the Potential impacts of HydRaUlic FracturING ON DRINKING Water Resources 19 (2011) [hereinafter EPA STUDY], archived at http://perma.cc/WB9W-VG7Y.

63. Envtl. Prot. Agency, Study of the Potential Impacts of Hydraulic Fracturing on Drinking Water Resources: Progress RePort 14 (2012) [hereinafter PROGRESS REPORT], archived at http://perma.cc/Z793-3AVN.

64. US EPA is studying the impacts of hydraulic fracturing in drinking water by examining the five stages of the fracking water cycle, specifically water acquisition, chemical mixing, well injection, flowback and produced water and wastewater treatment and waste disposal. Id. at 8, 14.

65. What is Shale Gas and Why is it Important?, supra note 34.

66. Natural Gas Extraction - Hydraulic Fracturing, EPA, http://www2.epa.gov/ hydraulicfracturing (last updated Nov. 11, 2013, archived at http://perma.cc/LWG8-VWAP).

67. What is Shale Gas and Why is it Important?, supra note 34.

68. See PrIMER, supra note 33, at 68.

69. See PRIMER, supra note 33, at 51-53. 
formation. ${ }^{70}$ Furthermore, injection must be conducted in a manner that prevents contamination of any underground sources of drinking water. ${ }^{71}$

As an alternative to storage or injection, some shale gas wastewater is discharged to publicly owned treatment works (POTWs); however, these POTWs are not always equipped to properly handle the constituents of this type of wastewater. ${ }^{72}$ Total dissolved solids, chloride, and bromide, for example, are some of the main pollutants of concern for POTWs ${ }^{73}$ and have the ability to "pass-through" the treatment facility or cause "interference" with a POTW's operation, such as contamination of biosolids. ${ }^{74}$ Understanding the quality and quantity of the wastewater that is to be discharged to a POTW as well as assessing the impact of the wastewater on its treatment and operations are paramount for the successful treatment of fracking wastewater and a POTW's compliance with its NPDES ${ }^{75}$ permit terms and conditions. ${ }^{76}$

Shale gas operators may also seek to recycle produced water for use in the fracking process, rather than rely on fresh water. ${ }^{77}$ Gas producers have accelerated such efforts to decrease costs associated with procuring fresh water, transport of wastewater, and offsite treatment and disposal. ${ }^{78}$ Moreover, given the large amounts of fresh water used, it is no surprise that states are increasingly advocating recycling efforts and use of non-potable water. $^{79}$ The challenge, ultimately, is to treat the wastewater to an

70. See PRIMER, supra note 33, at 68-69 (stating that underground injection is limited in the Marcellus Shale).

71. 40 C.F.R. $\$ 144.11$ (1993) (U.S. EPA UIC rules).

72. See EPA FAQ, supra note 44 , at 6 . Natural formation water can have very high levels of total dissolved solids (TDS), in excess of $400,000 \mathrm{ppm}$, that are very difficult to treat and not addressed by current effluent limitation guidelines or water quality standards. See EPA FAQ, supra note 44, at 10-12; PrIMER, supra note 33, at 67-68. Other chemical additives, metals and naturally occurring radioactive materials (NORM) are also present in fracking wastewater. See EPA FAQ, supra note 44, at 10-11, 15-16. U.S. EPA is developing a proposed rule to amend the Effluent Limitations Guidelines (ELGs) for the Oil and Gas Extraction Category. See 40 C.F.R. Part 435, Subpart C. The proposed rule is scheduled for publication in 2014. Unconventional Extraction in the Oil and Gas Industry, EPA, http://water.epa.gov/scitech/wastetech/guide/oilandgas/unconv.cfm (last updated Aug. 7, 2013, archived at $\mathrm{http}: / /$ perma.cc/4FK-VW6P).

73. EPA FAQ, supra note 44, at 10-11.

74. See EPA FAQ, supra note 44, at $8,10-11$; see also Biosolids Compliance Monitoring, EPA, http://www.epa.gov/compliance/monitoring/programs/cwa/biosolids.html (last updated July 17, 2013, archived at http://perma.cc/9Q8D-RDH7) (providing description of biosolids and compliance monitoring).

75. National Pollutant Discharge Elimination System, 33 U.S.C. $\$ 1342$ (2013).

76. See EPA FAQ, supra note 44 , at 9.

77. See PRIMER, supra note 33, at 68.

78. EPA STUDY, supra note 62, at 104 .

79. One example would be to use acid mine drainage from abandoned mining sites; however, this presents another set of concerns vis-à-vis liability under Superfund. Any party using acid mine drainage from a mine would likely be considered an "operator" and subject 
acceptable quality for reuse for hydraulic fracturing operations.

\section{Air}

The oil and gas industry is a significant source of volatile organic compounds (VOCs) which contribute to the formation of ground-level smog. ${ }^{80}$ There have been well-documented air quality impacts in areas with natural gas development, demonstrating increases in not only VOCs, but also methane and hazardous air pollutants (HAPs), such as benzene, ethylbenzene, and n-hexane. ${ }^{81}$ Pollution is emitted from various processes and equipment within the industry that prepare gas for sale and assist in moving it through pipelines and also during flowback. ${ }^{82}$ Sources can include mobile sources such as trucks, sweetening units, glycol dehydrators, well completions, leaks, and gas driven devices. ${ }^{83}$

\section{Impacts to Land}

Hydraulic fracturing has contributed to soil contamination, increased seismic activity, and high concentrations of radioactive material being brought to the surface during the fracking process. ${ }^{84}$ Chemically tainted soil from drilling waste has increased approximately 5,000 percent over the past decade. ${ }^{85}$ Moreover, injection of fracking wastewater has routinely produced micro-earthquakes, which have a magnitude lower than two. ${ }^{86}$ These induced quakes increase pressure on seismic faults and make them

to liability under CERCLA, unless some Good Samaritan exceptions or protections can be carved out. See Liability Concerns Hamper States' Bid to Use Acid Mine Water for Fracking, INSIDE EPA, http://insideepa.com/Superfund-Report/Superfund-Report07/22/2013/liability-concerns-hamper-states-bid-to-use-acid-mine-water-for-fracking/menuid-1094.html (July 22, 2013, archived at http://perma.cc/VB63-W3UQ).

80. EPA, OVERVIEW OF FINAL AMENDMENTS TO AIR REGULATIONS FOR THE OIL AND Natural Gas Industry: Fact SheEt 3 [hereinafter EPA Fact Sheet], archived at http://perma.cc/PE8E-CHTY.

81. Id.; see Hazardous Air Pollutants (HAPS), ALS ENVTL. (last visited Jan. 25, 2014), http://www.caslab.com/Hazardous-Air-Pollutants-HAPs (providing additional information on Hazardous Air Pollutants); Basic Information, EPA, http:/www.epa.gov/airquality/ oilandgas/basic.html (last updated Oct. 10, 2012, archived at http://perma.cc/9JNT-RSCA).

82. EPA FACT SHEET, supra note 80.

83. PRIMER, supra note 33, at 37, 72; 40 C.F.R. Part 60, Subpart OOOO (Standards of Performance for Crude Oil and Natural Gas Production, Transmission, and Distribution); EPA FACT SHEET, supra note 80.

84. Sharon Begley, Study Raises New Concern About Earthquakes and Fracking Fluids, REUTERS, July 11, 2013, archived at http://perma.cc/B2FE-JSH8 (citing William Ellsworth, Injection Induced Earthquakes, SCIENCE (July, 2013), http://www.sciencemag.org/content/ 341/6142/1225942.full; PRIMER, supra note 33, at 70; Joe Hoffman, Potential Health and Environmental Effects of Hydrofracking in the Williston Basin, Montana, in HEALTH CASE STUDIES- MONT. STATE UNIV. (2012), archived at http://perma.cc/652-JAST.

85. Hoffman, supra note 84.

86. Hoffman, supra note 84. 
more likely to slip. ${ }^{87}$ Research increasingly indicates a credible connection between wastewater injection activities and earthquakes, based on proximity and timing of the injection activities. ${ }^{88}$ These earthquakes are larger than micro-earthquakes ${ }^{89}$ and in the last four years alone, have surged 11 -fold from the three decades prior. ${ }^{90}$ Even more significant is the recent finding that injection wells can provide a foundation for more dangerous quakes, because pressure from wastewater wells stresses nearby faults, leaving them critically loaded or on the verge of rupture if seismic waves moving across the Earth's surface hit the fault. ${ }^{91}$ The result is what scientists are calling "dynamic triggering," weak seismic waves from faraway quakes that can set off a number of small quakes at well sites. ${ }^{92}$

Certain soils and geologic formations naturally contain low levels of radioactive material known as naturally occurring radioactive material, or NORM. ${ }^{93}$ Small amounts can be brought to the surface during the natural gas production process in both produced water and drill cuttings. ${ }^{94}$ Examples of NORM include radium, uranium, and thorium. ${ }^{95}$ While low concentrations may pose little risk, there is concern that accumulation of sludge inside tanks, process vessels, or in piping and equipment can occur

87. Hoffman, supra note 84 .

88. Frequently Asked Questions, U.S. Geological Survetp://www.usgs.gov/faq/?qy, $\mathrm{ht}=$ categories/9833/3287 (last updated May 13, 2013, archived at http://perma.cc/AX8QZH54). The magnitude 4 earthquake near Youngstown, Ohio on December 31, 2011 has been connected to wastewater disposal activities. Id.; see also Mark Fischetti, Ohio Earthquake Likely Caused by Fracking Wastewater, Scientific American (Jan. 4, 2012), http://www.scientificamerican.com/article.cfim?id=ohio-earthquake-likely-caused-by-fracking, archived at http://perma.cc/4XDD-SGXW; Becky Oskin, Early Warning Signs of InjectionWell Earthquakes Found, LIVESCIENCE, http://www.livescience.com/38117-understandinginduced-earthquakes-injection-wells.html (July 11, 2013, archived at http://perma.cc/E499JHCA); seismologists at Columbia University have identified three quakes in Oklahoma, Colorado and Texas that were triggered at injection well sites by major earthquakes a long distance away. Sharon Begley, supra note 84; see also Wastewater Injection Spurred Biggest Earthquake Yet, Says Study, THE EARTH InSTTTUTE: COlumBIA UNIVERSITY, http://www.earth.columbia.edu/articles/view/3072 (last visited Jan. 24, 2014, archived at http://perma.cc/9SSN-92YQ).

89. The Prague, Oklahoma earthquake, 5.7 in magnitude and felt 800 miles away in Milwaukee, WI, is perhaps the largest such earthquake to date linked to wastewater injection. Wastewater Injection Spurred Biggest Earthquake Yet, Says Study, supra note 88; see also S. HoRTON, Disposal of HydROFRACKING WASTE FLUID BY INJECTION INTO Subsurface aQuifers Triggers EarthQuake SWarm IN Central arkansas With POTENTIAL FOR DAMAGING EARTHQUAKE (2012), archived at http://perma.cc/65DK-DGPJ.

90. Sharon Begley, supra note 84.

91. Sharon Begley, supra note 84.

92. Sharon Begley, supra note 84.

93. PRIMER, supra note 33 , at 70 .

94. PRIMER, supra note 33 , at 70.

95. PRIMER, supra note 33 , at 70 . 
over time, thereby endangering the health of workers. ${ }^{96}$ A more serious concern is that radioactive material brought to the surface will contaminate land for many years. ${ }^{97}$ Radium-226 is the main radioactive element found in the Marcellus shale ${ }^{98}$ and has a half-life of 1,600 years. $^{99}$ NORM can remain active and potentially lethal and also bio-accumulate in the food chain, eventually reaching humans. ${ }^{100}$ In the Marcellus Shale, concentrations of NORM in fracking wastewater have been found to be substantially higher than the Maximum Contaminant Levels (MCLs) for drinking water. ${ }^{101}$ Wastewater with high concentrations of NORM can impact treatment facilities, ${ }^{102}$ and discharge of wastewater from a treatment facility could result in a discharge of radioactive contaminants, possibly impacting downstream public water systems or water quality standards. ${ }^{103}$

\section{Impacts to Animals and Habitats}

The environmental effects of fracking are multi-faceted. Adverse impacts of shale gas production on water and air, resulting in degradation of air and water quality, will have negative impacts on wildlife, livestock and aquatic organisms. ${ }^{104}$ These effects can be numerous and varied and will depend on several factors, such as the sensitivity of the species and the nature of the disruption. ${ }^{105} \mathrm{~A}$ recent study by Cornell University concluded that livestock experienced neurological, reproductive and gastrointestinal

96. PrIMER, supra note 33, at 71; EPA FAQ, supra note 44, at 15.

97. E. Ivan White, Consideration of Radiation in Hazardous Waste Produced FROM HORIZONTAL HYDROFRACKING 5 (Grassroots Envtl. Educ., 2012), archived at http://perma.cc/B743-GCH7 (stating that the type of radioactive material found in the Marcellus Shale is particularly long-lived).

98. Courtney Sperger, et al., Does Marcellus Shale Pose a Radioactivity Risk?, THE INST. FOR ENERGY AND ENVTL. RES. FOR NORTHEASTERN PA., http://energy.wilkes.edu/ pages/184.asp (last updated Aug. 1, 2012, archived at $\mathrm{http}: / /$ perma.cc/ZXS5-6EGE).

99. Radium, EPA, http://www.epa.gov/radiation/radionuclides/radium.html (last updated Mar. 6, 2012, archived at http://perma.cc/V7MG-5W4J).

100. WHITE, supra note 97.

101. EPA FAQ, supra note 44, at 16. (radium 226 and Alpha particles have been found in concentrations up to $16,030 \mathrm{pCi} / \mathrm{l}$ and $18,950 \mathrm{pCi} / 1$, respectively; the $\mathrm{MCL}$ for Radium 226 is $5 \mathrm{pCi} / 1$ and $15 \mathrm{pCi} / /$ for Alpha particles).

102. EPA FAQ, supra note 44 , at 16 (contamination of sludge or scale buildup on equipment).

103. EPA FAQ, supra note 44, at 16.

104. See Ronald Bishop, Chemical and Biological Risk Assessment for Natural Gas Exploration in New York, SUSTAINABLE OTSEGO, http://www.sustainableotsego.org/ Risk\%20Assessment\%20Natural\%20Gas\%20Extraction-1.htm (Mar. 28, 2011, archived at http://perma.cc/D2LH-DX8Q); MARIANE BROMLEY, WILDLIFE MANAGEMENT IMPLICATIONS OF PETROLEUM EXPLORATION AND DEVELOPMENT IN WildLAND ENVIRONMENTS 1-2 (1985) archived at http://perma.cc/5F22-SDJJ.

105. See PRIMER, supra note 33, at 48; BROMLEY, supra note 104. 
problems after being exposed to fracking fluids either accidentally or incidentally. ${ }^{106}$ Water acquisition has also had critical effects on fish and aquatic life by depleting necessary water levels. ${ }^{107}$ Yet another impact of the fracking process is increased traffic. ${ }^{108}$ Construction of access roads necessary for well construction, transport of water, sand and chemicals for injection, and removal of wastewater can "fragment" field and forest habitats, ${ }^{109}$ which, in turn, threaten sensitive plants and animal species. ${ }^{110}$

\section{REGULATORY APPROACH IN THE UNITED STATES}

There is no comprehensive umbrella statute dealing with fracking, although repeated attempts have been made to pass legislation that would cover fracking operations and require disclosure and permits before drilling. ${ }^{111}$ Various federal environmental statutes regulate most aspects of shale gas development. ${ }^{112}$ In particular, eight federal environmental and public health laws apply to unconventional oil and gas development: the Safe Drinking Water Act (SDWA); Clean Water Act (CWA); Clean Air Act (CAA); Resource Conservation and Recovery Act (RCRA); Comprehensive Environmental Response; Compensation and Liability Act (CERCLA); Emergency Planning and Community Right-to-Know Act (EPRCA); Toxic Substances Control Act (TSCA); and the Federal Insecticide, Fungicide,

106. Bamberger \& Oswald, supra note 13 , at 61 .

107. PRIMER, supra note 33, at 65 .

108. See N.Y. State Dep'T of Envtl. Conserv., Supplemental Generic ENVIRONMENTAL IMPACT STATEMENT 6-300 (2011), archived at http://perma.cc/RM4-XDNL (noting that there are numerous accounts at fracking sites of incessant truck traffic, dangerous driving and strain on local budgets due to the increased need for road maintenance); traffic also results in nuisance impacts such as increased noise, dust, and visual clutter. See Jim Efstathiou Jr., Taxpayers Pay as Fracking Trucks Overwhelm Rural Cow Paths, Bloomberg News (May 15, 2012, archived at http://perma.cc/LV8-CSJJ); Chris Davidson, With Fracking Prosperity Comes Fracking Traffic, THE NEws OUTLET (last visited Jan. 24, 2014, archived at http://perma.cc/TT5J-ASR5); Ryan Delaney, Fracking Will Bring Heavy Truck Traffic, but Towns are Ready, InNOvaTION Trall (Sept. 4, 2012, archived at http://perma.cc/LQH8-63F2).

109. N.Y. STATE DEP'T OF ENVTL. CONSERV. 6-300. ("Fragmentation is an alteration of habitats resulting in changes in area, configuration, or spatial patterns from a previous state of greater continuity, and usually includes the following: [r]eduction in the total area of the habitat; [d]ecrease of the interior to edge ratio; [i] solation of one habitat fragment from other areas of habitat: [b]reaking up of one patch of habitat into several smaller patches; and [d] ecrease in the average size of each patch of habitat.") (alterations added).

110. Id. at 6-68.

111. See Fracturing Responsibility and Awareness of Chemicals Act of 2013, H.R. 1921, 113th Cong. (1st Sess. 2013).

112. See generally U.S. Gov'T ACCOUNTABILITY OFFICE, UNCONVENTIONAL OIL AND GAS DEvelopment: Key ENVIRONMENTAL and Public HEALth REQUiRements (2012), archived at http://perma.cc/633Z-XZYH. 
and Rodenticide Act (FIFRA). ${ }^{113}$ States may promulgate their own rules and be granted "primacy," whereby they obtain primary jurisdiction and implement a particular program with federal oversight as long as a state's standards are at least as protective as, or no less stringent than, the federal standards. ${ }^{114}$ While some portions of the aforementioned federal laws apply to unconventional oil and gas development, ${ }^{115}$ there are key exemptions or limitations in regulatory coverage that affect the applicability of these laws. ${ }^{116}$ As discussed below, EPA is evaluating existing authority with respect to fracking. This section will examine the current legal framework as it relates to hydraulic fracturing and highlight recent developments affecting the authority to regulate the process.

\section{A. Safe Drinking Water Act}

SDWA authorizes EPA to set national health-based standards for drinking water to protect against both naturally-occurring and man-made contaminants that may be found in drinking water. ${ }^{17}$ SDWA also authorizes EPA to regulate the underground injection of fluids and establishes the Underground Injection Control (UIC) program, responsible for regulating the construction, operation, permitting, and closure of injection wells that place fluids underground for storage or disposal. ${ }^{118}$ The UIC program protects underground sources of drinking water (USDWs) by setting requirements for injection wells that prevent endangerment to USDWs. ${ }^{119}$ In the Energy Policy Act of 2005, Congress exempted fracking from regulation under the Safe Drinking Water Act and redefined the definition of "underground injection" to exclude "the underground injection of fluids or propping agents (other than diesel fuels) pursuant to hydraulic fracturing operations related to oil, gas, or geothermal production activities. ${ }^{\prime 20}$ This amendment exempted hydraulic fracturing from the UIC

113. Id. at 17 (containing a comprehensive discussion of each statute).

114. See Primacy, EPA, http://water.epa.gov/infrastructure/drinkingwater/pws/ primacy.cfm (last updated Oct. 11, 2012, archived at http://perma.cc/4S2U-AKW2) (states may also opt for stricter standards).

115. U.S. Gov'T ACCOUNTABILITY OFFICE, supra note 112, at 43 (discussing pesticide requirements under FIFRA and the regulation of the use, sale and distribution of pesticides, such as biocides used by the industry to kill bacteria or other organisms that may interfere with the hydraulic fracturing process).

116. U.S. GOV'T ACCOUNTABILITY OFFICE, supra note 112, at 44.

117. Safe Drinking Water Act of 1974,42 U.S.C. $\S \S 300 \mathrm{f}$ et. seq.

118. See generally 42 U.S.C. $\S 300 \mathrm{~h}$.

119. Underground Injection Control Program, 40 C.F.R. § 144 (2013); PrIMER, supra note 33 , at 32 .

120. Energy Policy Act 2005, Pub. L. No. 109-58, 119 Stat. 594 (2005); 42 U.S.C. $\S$ $300 \mathrm{~h}(\mathrm{~d})(1)(2013)$. 
provisions in SDWA, provided diesel fuel was not used. ${ }^{121}$ Currently, both the injection of diesel fuels during hydraulic fracturing and injection of flowback and produced water are subject to UIC permitting requirements. ${ }^{122}$ In May of 2012, EPA issued a draft UIC program permitting guidance for fracking injection activities using diesel fuels. ${ }^{123}$ Specifically, Class II wells are used for the injection of fluids associated with oil and natural gas production activities. ${ }^{124}$ In states where EPA has approved primacy ${ }^{125}$ for the UIC program, state agencies issue permits and oversee injection activities. $^{126}$

Section 1431 of SDWA gives EPA the authority to take action whenever the agency receives information that a contaminant is present in or is likely to enter a public water system or a USDW, the contaminant may present an imminent and substantial endangerment to human health, and when appropriate State and local authorities have not acted to protect public health. ${ }^{127}$

Recently, EPA began research regarding the potential impacts of

121. 42 U.S.C. $\S 300 \mathrm{~h}(\mathrm{~d})(1)$ (2013); see also Regulation of Hydraulic Fracturing under the Safe Drinking Water Act, EPA, http://water.epa.gov/type/groundwater/uic/ class2/hydraulicfracturing/wells_hydroreg.cfm (last updated May 4, 2012, archived at http://perma.cc/U2Q5-937Z); U.S. Gov'T ACCOUNTABILITY OFFICE, supra note 112, at 21.

122. 40 C.F.R. $\S 144.11$ (2013); U.S. Gov'T ACCOUNTABILITY OFFICE, supra note 112, at 18,21 (under the UIC regulatory framework, wells that inject fluids associated with oil and natural gas production activities are classified as Class II wells).

123. See Envtl. Prot. Agency, Permitting Guidance for Oil and Gas Hydraulic Fracturing ACtivities Using Diesel Fuels - Draft: Underground INJECTION CONTROL PROGRAM GUIDANCE \#84 7-8 (2012) archived at http://perma.cc/UQW7-4WSX. Diesel fuels may be used in hydraulic fracturing operations as a primary base (or carrier) fluid, or added to hydraulic fracturing fluids as a component of a chemical additive to adjust fluid properties (e.g., viscosity and lubricity) or act as a solvent to aid in the delivery of gelling agents. $I d$. On February 11, 2014, EPA issued revised guidance on the use of diesel fuels in fracking. EPA Revises Permitting Guidance for Using Diesel Fuel in Oil and Gas Hydraulic Fracturing, EPA, http://yosemite.epa.gov/opa/admpress.nsf/6427a6b7538955c5852573590 03f0230/1bff69764b49be5b85257c7c006b0f4d!OpenDocument (last updated Feb. 28, 2014, archived at http://perma.cc/CS89-AFDR).

124. Id.

125. See State UIC Program Requirements, 40 C.F.R. $\S 145$ (2012) (detailing state permitting requirements for primacy).

126. UIC Program Primacy, EPA, http://water.epa.gov/type/groundwater/uic/ Primacy.cfm (last updated Aug. 1, 2012, archived at http://perma.cc/E22D-EPTK). EPA directly implements the UIC program in states without primacy. Id.

127. 42 U.S.C. $\S 300 \mathrm{i}(2013)$. In December 2010, EPA used this authority to issue an emergency administrative order to an operator in Texas alleging that the company's oil and gas production facilities caused or contributed to methane in two nearby private drinking water wells. Range Resources Imminent and Substantial Endangerment Order, Parker County, TX, EPA, http://www.epa.gov/region6/region-6/tx/tx005.html (last updated July 20, 2011, archived at http://perma.cc/3HMS-4J3W). 
hydraulic fracturing on drinking water resources. ${ }^{128}$ Specifically, the study seeks to analyze whether fracking has an impact on drinking water resources and identify the driving factors that may affect the severity and frequency of those impacts. ${ }^{129}$ Its scope focuses on the five stages of the hydraulic fracturing water life-cycle: 1) water acquisition; 2) chemical mixing; 3) well injection; 4) flowback and produced water; and 5) wastewater treatment and waste disposal. ${ }^{130}$ A progress report in December 2012 described eighteen ongoing research projects and projected that a draft report subject to peer review and comment would be released in $2014 .{ }^{131}$

\section{B. Clean Water Act}

Shale gas extraction produces copious amounts of wastewater from the hydraulic fracturing process that contains total dissolved solids, naturally occurring radioactive materials, metals, and other chemicals used as additives. ${ }^{132}$ The CWA regulates both direct and indirect discharges into waters of the United States. ${ }^{133}$ Direct discharges of such pollutants by point sources into waters of the United States are prohibited, except in compliance with a NPDES permit. ${ }^{134}$ Shale gas production sites or industrial and municipal facilities that handle the disposal or treatment of wastewater from shale gas production must obtain NPDES permits if they intend to discharge directly. ${ }^{135}$ Effluent limitations in a NPDES permit are the primary mechanisms for controlling discharges of pollutants. ${ }^{136}$

The EPA promulgated the Oil and Gas Extraction (O\&G) effluent limitations guidelines (ELGs) for wastewater discharges from field exploration, drilling, production, well treatment, and well-completion activities. ${ }^{137}$ However, there are no comprehensive standards for the

128. EPA STUDY, supra note 62 , at 1 . Congress directed EPA to conduct a study to examine the relationship between hydraulic fracturing and drinking water. H.R. REP. No. 111-316, at 109 (2009) (Conf. Rep).

129. EPA STUDY, supra note 62, at 1.

130. EPA STUDY, supra note 62 , at 1 .

131. PROGRESS REPORT, supra note 63.

132. PrIMER, supra note 33, at 61-64.

133. Direct discharges are regulated under the NPDES program under Section 402 of the Clean Water Act. Indirect discharges are regulated under the Pretreatment Program under Section 307(b) of the Clean Water Act.

134. 33 U.S.C. $\$ 1311$ (a) (2011).

135. Id.

136. PRIMER, supra note 33, at 30. NPDES permits will contain limits based on the technology available to control the pollutants (technology-based limits) which are set on an industry-wide basis, as well as limits to protect water quality of the receiving water (water quality-based effluent standards). 40 C.F.R. $\S \S 435.12$ - 435.14 (2011). NPDES permits also contain monitoring and reporting requirements and other standard conditions. See 40 C.F.R. $\S 122.41(2011)$.

137. Oil and Gas Extraction Effluent Guidelines, EPA, 
disposal of wastewater discharged from natural gas extraction activities from unconventional resources. ${ }^{138}$ As a result, in October 2011, EPA announced a schedule to amend the $O \& G$ guidelines and develop not only standards for extraction from underground coal-bed and shale formations but also pretreatment requirements ${ }^{139}$ to ensure that fracking wastewaters receive proper treatment and can be handled by POTWs. ${ }^{140}$ On August 7 , 2013, EPA announced that it plans to delist coal-bed methane rulemaking; however, the Agency will continue to develop revisions to the Oil and Gas ELGs to address the unconventional oil and gas industry. ${ }^{141}$

With respect to stormwater discharges, while facilities are required to obtain NPDES permits for discharges of stormwater associated with industrial or construction activities, operators of oil and gas well sites are largely exempt from these requirements. ${ }^{142}$ There is no requirement for oil and gas production facilities to obtain a NPDES permit unless there is a reportable quantity spill or discharge that causes or contributes to a water quality violation. ${ }^{143}$

Finally, section 311 of the CWA provides requirements to prevent discharges of oil from vessels and facilities. The Spill Prevention Control and Countermeasures (SPCC) rule requires facilities meeting applicability criteria to develop a spill prevention plan and implement oil spill prevention measures. ${ }^{144}$ Onshore oil and gas well sites are subject to this rule if they have a total aboveground oil storage capacity greater than 1,320 gallons and could reasonably be expected to discharge oil into US navigable waters. ${ }^{145}$

http://water.epa.gov/scitech/wastetech/guide/oilandgas/index.cfm (last updated Apr. 12, 2013, archived at $\mathrm{http}: / /$ perma.cc/882Q-9YKZ).

138. Natural Gas Extraction-Hydraulic Fracturing, supra note 66.

139. See General Pretreatment Regulations for Existing and New Sources of Pollution, 40 C.F.R. Part 403 (2013). Indirect discharges to POTWs are subject to these regulations. Id.

140. Notice of Final 2010 Effluent Guidelines Program Plan, 76 Fed. Reg. 66286 (Oct. 26, 2011), archived at http://perma.cc/533V-NPFL.

141. Unconventional Extraction in the Oil and Gas Industry, EPA, http://water.epa.gov/scitech/wastetech/guide/oilandgas/unconv.cfm (last updated Aug. 7, 2013, archived at http://perma.cc/DGH9-N26B).

142. Natural Gas Extraction - Hydraulic Fracturing, supra note 66; U.S. Gov'T ACCOUNTABILITY OFFICE, supra note 112, at 26.

143. Regulation of Oil and Gas Construction Activities, EPA, http://cfpub.epa.gov/npdes/stormwater/oilgas.cfm (last updated Dec. 6, 2012, archived at http://perma.cc/FH72-FSJC).

144. Oil Pollution Prevention, 40 C.F.R. $\$ 112.1$ (2013).

145. U.S. Gov'T ACCOUNTABILITY OFFICE, supra note 112, at 27. Most hydraulic fracturing operations include oil storage in excess of these thresholds. U.S. Gov'T ACCOUNTABILITY OFFICE, supra note 112 , at 27 ; see also Oil Spills, EPA, http://www.epa.gov/oilspill (last updated Dec. 13, 2011, archived at http://perma.cc/FJ5BWRML). 


\section{Clean Air Act}

Shale gas producers have a duty to comply with existing Clean Air Act regulations and obtain air permits for any number of emissions sources. ${ }^{146}$ Producers also have an ongoing obligation to update information concerning their fracking operations that might require a permit amendment or more stringent permit. ${ }^{147}$ The EPA recently issued the first regulations aimed at reducing air pollution from fracking. ${ }^{148}$ These new National Emission Standards for Hazardous Air Pollutants (NESHAPs) and New Source Performance Standards (NSPS) are expected to yield a nearly 95 percent reduction in VOCs emitted from more than 11,000 new fracked gas wells a year. ${ }^{149}$ This would be accomplished through "green completions," which capture toxic emissions from flowback and prevent escape to the air. ${ }^{150}$ Also, on August 2, 2013, EPA issued final updates to its 2012 Oil and Gas Performance Standards to address VOC emissions from storage tanks. ${ }^{151}$ These tanks are used to temporarily hold liquids produced during the production and transmission of oil and natural gas. ${ }^{152}$ The requirements will apply to storage tanks that have the potential to emit six or more tons of VOCs a year. ${ }^{153}$ These regulatory updates were in response to several petitions for reconsideration after EPA issued its final rule. ${ }^{154}$ The Agency continues to evaluate other issues raised in those petitions. ${ }^{155}$

\section{Toxic Substances Control Act, Federal Insecticide Fungicide and Rodenticide Act, and Bureau of Land Management}

The Toxic Substances Control Act (TSCA) authorizes EPA to regulate the manufacture, processing, use, distribution, and disposal of

146. Some examples of sources include gas compressor engines, glycol dehydrators, and flares. PRIMER, supra note 33, at 37.

147. PRIMER, supra note 33 , at 37.

148. Oil and Natural Gas Sector: New Source Performance Standards and National Emission Standards for Hazardous Air Pollutants Reviews, 77 Fed. Reg. 49490 (Apr. 17, 2012) (to be codified at 40 C.F.R. pt. 60 and 63), archived at http://perma.cc/C6R-J6D3.

149. EPA FACT SHEET, supra note 80.

150. EPA FACT SHEET, supra note 80.

151. EnVtl. Prot. Agency, Final Updates to Requirements for Storage Tanks Used In OIL and Natural Gas PRODUCtion AND TRANSmission (2012), archived at http://perma.cc/3MGS-RN2M; see Standards of Performance for New Stationary Sources, 40 C.F.R. $\S 60$ (1971).

152. Envtl. Prot. Agency, Final Updates to Requirements for Storage Tanks Used in Oil and Natural Gas Production and Transmission 1 (2012), archived at http://perma.cc/3MGS-RN2M.

153. Id.

154. Id.

155. Id. 
chemical substances and mixtures. ${ }^{156}$ The Agency executes this authority through the collection of information about chemical substances requiring companies to conduct testing on chemical substances, and taking action to protect against unreasonable risks. ${ }^{157}$ The list of chemicals manufactured in the United States is maintained on the TSCA Inventory. ${ }^{158}$ The EPA is currently analyzing a list of chemicals submitted by oil and gas companies as part of its study examining the impacts of fracking on water resources. ${ }^{159}$ In August 2011, the Agency received a petition from Earthjustice and other organizations requesting that EPA promulgate rules to protect human health and the environment from the risks of Exploration and Production (E\&P) chemicals. ${ }^{160}$ The Earthjustice petition specifically sought to require manufacturers and processors to conduct toxicity testing, maintain records, and submit reports on any adverse environmental or health effects. ${ }^{161}$ Petitioners noted concern about inadequate information on the health effects associated with those chemicals. ${ }^{162}$ The EPA granted the petition in part and agreed to move forward with a proposed rulemaking process to obtain data on chemical substances and mixtures used in hydraulic fracturing, albeit not committing to a specific rule-making outcome. ${ }^{163}$ However, the Agency found that "petitioners have not set forth sufficient facts to support their assertion that it is necessary to issue a TSCA section 4 rule requiring testing of all chemical substances and mixtures used in all oil and gas E\&P."164 The Agency will first develop an Advance Notice of Proposed Rulemaking (ANPRM) and initiate a stakeholder process to provide input on the design and scope of the TSCA reporting requirements that would be included in a proposed rule. ${ }^{165}$

The Federal Insecticide, Fungicide, and Rodenticide Act (FIFRA) grants EPA the authority to regulate the use, distribution, and sale of pesticides to protect human health and the environment. ${ }^{166}$ All pesticides for

156. 15 U.S.C. $\S \S 2601-2692$ (2012); U.S. Gov’T ACCOUNTABILITY OFFICE, supra note 112 , at 41 .

157. U.S. Gov'T ACCOUNTABILITY OFFICE, supra note 112, at 41 .

158. Toxic Substances Control Act of $1976 \S 8(\mathrm{~b}), 15$ U.S.C. $\S 2607$ (2013).

159. EPA STUDY, supra note 62, at 3.

160. Letter from Deborah Goldberg, Earthjustice, to Lisa P. Jackson, Adm'r, Envtl. Prot. Agency (Aug. 4, 2011), archived at $\mathrm{http}: / /$ perma.cc/6YCK-KCB7.

161. Id.

162. Letter from Stephen A. Owens, Assistant Adm'r, Envtl. Prot. Agency to Deborah Goldberg, Earthjustice (Nov. 23, 2011), archived at http://perma.cc/T9BY-X86A.

163. Chemical Substances and Mixtures Used in Oil and Gas Exploration or Production[,] TSCA Section 21 Petition[,] Reasons for Agency Response, 78 Fed. Reg. 133 (proposed July 11, 2013) (to be codified at 40 C.F.R. 1) (alterations added), archived at http://perma.cc/MZ7L-8ZSZ.

164. 78 Fed. Reg. 41770 (2013).

165. 78 Fed. Reg. 41769 (2013).

166. See Federal Insecticide, Fungicide, and Rodenticide Act, 7 U.S.C. $\S \S 136-136 y$ (2011); see also Federal Insecticide, Fungicide, and Rodenticide Act (FIFRA), EPA, 
sale in the United States must be registered, and use of any particular pesticide must be consistent with use directions on its label or labeling. ${ }^{167}$ Biocides are commonly used by operators during fracking for their antimicrobial properties and ability to inhibit algal growth. ${ }^{168}$ Commonly used biocides are registered as pesticides under FIFRA, and EPA has approved some of these for use in fracking fluid. ${ }^{169}$

However, state regulators have questioned whether the use of certain biocides is a violation of FIFRA, because their use would appear to constitute a pesticide application, and drilling companies mix certain industrial grade compounds to serve as biocides without those compounds being technically labeled for such use. ${ }^{170}$ Nevertheless, EPA has recently clarified that it has no plans to use FIFRA to regulate fracking beyond its mandated registration responsibilities. ${ }^{171}$ Many of the registered products are labeled with fracturing as a use, but are not required to have that designation as long as the product is registered for general use in oil and gas production. ${ }^{172}$ The EPA has stated that it is not considering new certification statements for general use biocides registered for oil and gas uses. ${ }^{173}$ The Agency is, however, examining registered biocides used in fracking in its drinking water study. ${ }^{174}$

Finally, the U.S. Department of the Interior's Bureau of Land Management (BLM) is proposing a rule to regulate hydraulic fracturing on public and Indian land. BLM is responsible for permitting and managing most onshore oil and gas activities on federal lands, and oversees approximately 700 million subsurface acres of federal mineral estate and 56

http://www.epa.gov/oecaagct/fra.html (last updated June 27, 2012, archived at http://perma.cc/XH8B-AYGC).

167. 7 U.S.C. $\S 136 \mathrm{a}$ (c) (2011); 40 C.F.R. $\S 156.10$ (2009).

168. U.S. GOV'T ACCOUNTABILITY OFFICE, supra note 112, at 43.

169. U.S. GOV'T ACCOUNTABILITY OFFICE, supra note 112, at 43; JENNIFER MCLAIN, EPA Registration of ANTIMICRobial Pesticides Used IN OIL AND Gas Industry (2013), archived at http://perma.cc/3UPL-JGHH; EPA Sees No FIFRA Oversight for Fracking Beyond Registration Role, INSIDEEPA (Mar. 21, 2013).

170. Steven M. Siros, State Regulators Question Whether Use of Biocides in Fracking Fluids Violates FIFRA, CORPORATE ENVIRONMENTAL LAWYER BlOG (Oct. 17, 2012, archived at http://perma.cc/6PK9-MNK3).

171. EPA Sees No FIFRA Oversight for Fracking Beyond Registration Role, supra note 169. Deputy Director of the Antimicrobials Division in the Office of Pesticide Programs (OPP), Jennifer McLain, noted that antimicrobials used in fracking are labeled with safety and use information that may be more specific or detailed than those registered under the general gas and oil production category. EPA Sees No FIFRA Oversight for Fracking Beyond Registration Role, supra note 169.

172. EPA Sees No FIFRA Oversight for Fracking Beyond Registration Role, supra note 169; see also MCLAN, supra note 169.

173. MCLAIN, supra note 169 , at 4.

174. MCLAIN, supra note 169 , at 4 . EPA identified several biocides in its drinking water study. EPA STUDY, supra note 62, at 110. 
million subsurface acres of Indian mineral estate across the United States. ${ }^{175}$ On May 16, 2013, the Bureau issued a draft rule that "would (1) provide disclosure to the public of chemicals used in hydraulic fracturing on public land and Indian land, (2) strengthen regulations related to well-bore integrity, and (3) address issues related to flowback water."176 BLM issued this rule to provide useful information to the public and to ensure that hydraulic fracturing is conducted in a way that adequately protects the environment. ${ }^{177}$ The Department of the Interior closed the public comment period on the rule on August 23, 2013. ${ }^{178}$

\section{HYDRAULIC FRACTURING IN THE EUROPEAN UNION}

The exploration and production of shale gas in the European Union remains in its infancy when compared to the United States. There are only a small number of EU Member States that are currently exploring or performing shale gas extraction, ${ }^{179}$ and the actual amounts of extraction vary significantly. So far, the United Kingdom has explored only one well. ${ }^{180}$ Poland, on the other hand, has drilled forty-three wells and sold over 100 concessions. ${ }^{181}$ At the same time, only twelve wells have produced actual gas flow in Poland, ${ }^{182}$ and no EU Member State has established any

175. New Energy for America, BUREAU OF LAND MGMT., http://www.blm.gov/wo/st/en/ prog/energy.html (last updated Feb. 6, 2013, archived at http://perma.cc/6ZXU-D8WS).

176. Oil and Gas[,] Well Stimulation, Including Hydraulic Fracturing, on Federal and Indian Lands, 77 Fed. Reg. 27691 (proposed May 11, 2012) (to be codified at 43 C.F.R. 3160) (alteration added), archived at http://perma.cc/HPX6-DGL9. Operators will be required to have appropriate plans in place to manage flowback waters from their fracturing operations. Id. at 27692.

177. Id. at 27691.

178. News Release, U.S. Dep't. of the Interior - Bureau of Land Mgmt., BLM Extends Public Comment Period on Proposed Hydraulic Fracturing Rule (June 7, 2013, archived at http://perma.cc/SEP7-CT92).

179. Philippe \& Partners, supra note 8; Directorate General for INTERNAL POLICIES, supra note 8, at 12.

180. Directorate General for INTERnal Policies, supra note 8, at 12.; contra, Vello KuUsKraA ET AL., World Shale Gas AND Shale OIL Resource AsSessment XI-3 (2013), available at http://www.eia.gov/analysis/studies/worldshalegas/pdf/fullreport.pdf?zscb=8352 9584.

181. Dimiter Kenarov, Poland: After The Shale Gas Bubble, PULITZER CEnTER, http://pulitzercenter.org/reporting/poland-pennsylvania-energy-shale-gas-fracking-farmingwater-bubble (Dec. 2, 2013, archived at http://perma.cc/F5FF-L5Z9); see also, Poland's Shale Gas Hopes Suffer Blow, FuEL FIX (May 8, 2013, archived at http://perma.cc/NJ652544); see also Shale Gas in Poland: Mad and Messy Regulation, ECONOMIST, Jul. 10, 2013, archived at http://perma.cc/G2ZD-6LDA; KUUSKRAA ET AL., supra note 180, at VIII-4. In Europe, mining rights are separate from property rights and need to be granted through state concessions or licenses.

182. Poland's Shale Gas Hopes Suffer Blow, supra note 181. 
type of commercial shale gas production. ${ }^{183}$ Regardless of these facts, the exploration of unconventional gas in all Member States must comply with applicable EU rules and permits may only be issued in accordance with those rules. While the EU has a comprehensive legislative framework on environmental protection and non-discriminatory access to hydrocarbon resources, ${ }^{184}$ the legislative framework lacks a clear and uniform character and does not directly refer or even apply to hydraulic fracturing. ${ }^{185}$ This creates the potential for regulatory gaps between Member States' jurisdictions by triggering regulatory uncertainty, significantly increasing transaction costs for exploring unconventional gas in Europe, and preventing "a fair and level playing field across the Union, in full compliance with relevant EU safety and environmental protection laws." 186

To be sure, the European Union does not have exclusive powers in the area of the environment and energy policy. ${ }^{187}$ Rather, the Union shares these powers with the Member States. ${ }^{188}$ Any Union action in the area of the environment or energy must therefore follow the principles of subsidiarity and proportionality ${ }^{189}$ and can only be taken "if and in so far as the objectives of the proposed action cannot be sufficiently achieved by the Member States." 190

183. See, e.g., Note from Janez Potocnik, Member of the European Comm'n, to Mr. Matthias Groote, Chair of the Env't Comm., at 2 (Jan. 26, 2012), archived at http://perma.cc/56CT-ZAL8; PHILIPPE \& PARTNERS, supra note 8, at 5 ๆ 1.

184. European Union, Commission Guidance Note on the Application of Directive 85/337/EEC to Projects Related to the Exploration and Exploitation of Unconventional Hydrocarbon (2011) [hereinafter Commission Guidance Note]; contra Ana-Maria Tolbaru, No Need for Further Regulation on Shale Gas: EU Study, EURACTIV (Jan. 30, 2012, archived at http://perma.cc/C53R-8D74)(noting the position of the World Wildlife Fund NGO that "[i]t is still too early for energy officials to conclude that existing EU laws do not need adjustment.").

185. See, e.g., Statement by Commissioner Potočnik Following the Vote in the European Parliament on Shale Gas, supra note 31 ("Studies carried out indicate that there are a number of uncertainties or gaps in current EU legislation and the Commission intends to deliver next year a framework to manage risks, address regulatory shortcomings, and to provide maximum clarity and predictability to market operators and citizens across the EU.").

186. Resolution on the Environmental Impacts of Shale Gas and Shale Oil Extraction Activities, PARL. EUR. DOC. A7-0283/2012 \ 2 (2012) [hereinafter EP Resolution], archived at http://perma.cc/NJS7-RGRD.

187. Consolidated Version of the Treaty on the Functioning of the European Union, arts. 191-194, May 9, 2008, 2008 O.J. (C 115) 47 [hereinafter TFEU].

188. Id.

189. Christoph Henkel, The Allocation of Powers in the European Union: A Closer Look at the Principle of Subsidiarity, 20 BERKELEY J. INT'L L. 359, 368 (2002).

190. Consolidated Version of the Treaty on the European Union, art. 5, July 29, 1992, 1992 O.J. (C 191) [hereinafter TEU] (emphasis added). 


\section{A. Environmental Protection in the European Union}

Environmental protection was never directly mentioned in the Founding Treaties of the European Communities. ${ }^{191}$ This changed with the implementation of the Single European Act (SEA), ${ }^{192}$ which added a new chapter on the environment to the Community Treaties. ${ }^{193}$ The power to determine environmental policies was further advanced as part of the Treaty of Maastricht, ${ }^{194}$ the Treaty of Amsterdam, ${ }^{195}$ and the Treaty of Nice. ${ }^{196}$ The Treaty of Lisbon, which is the latest amendment to the Founding Treaties of the European Union, did not include any additional changes or extend the Union's powers in the area of environmental protection. ${ }^{197}$

Before the enactment of the SEA, the power to develop environmental policies was only considered an implicit or inherent power of the Communities, necessary to ensure the establishment of the common market. ${ }^{198}$ However, national differences in environmental protection requirements for goods, products, and services eventually came to be

191. Treaty Establishing the European Economic Community, Mar. 25, 1957, 298 U.N.T.S. 11.

192. Single European Act, 1987 O.J. (L 169) 1.

193. Id. arts. 130r-130t.

194. Maastricht Treaty, art. 2, Feb. 7, 1992, 1992 O.J. (C 191), archived at http://perma.cc/8NNQ-7XUZ. For a summary on the Treaty of Maastricht, see Treaty of Maastricht on European Union, EUROPA, http://europa.eu/legislation_summaries/ institutional_affairs/treaties/treaties_maastricht_en.htm (last updated Oct. 15, 2010, archived at $\mathrm{http}: / /$ perma.cc/Y47Y-HKB3).

195. Treaty of Amsterdam Amending the Treaty on European Union, the Treaties Establishing the European Communities and Certain Related Acts, art. 1(2), Oct. 2, 1997, 1997 O.J. (C 340) 1 [hereinafter The Amsterdam Treaty], archived at http://perma.cc/BXW5-KHAX. For a summary, see The Amsterdam Treaty: $A$ Comprehensive Guide, EUROPA, http://europa.eu/legislation_summaries/institutional_affairs/ treaties/amsterdam_treaty/index_en.htm (last visited Sep. 20, 2013, archived at http://perma.cc/BXW5-KHAX).

196. Treaty of Nice Amending the Treaty on European Union, the Treaties Establishing the European Communities and Certain Related Acts, Mar. 10, 2001, 2001 O.J. (C 80) 1 [hereinafter Treaty of Nice], archived at http://perma.cc/AEH6-HGV4. For a summary, see Treaty of Nice: A Comprehensive Guide, EUROPA, http://europa.eu/legislation_summaries/ institutional_affairs/treaties/nice_treaty/index_en.htm (last visited Jan. 29, 2014, archived at http://perma.cc/GT9J-9QEU).

197. Hans Vedder, Analysis: The Treaty of Lisbon and European Environmental Law and Policy, 22 J. ENVTL. L. 285 (2010); Jan H. Jans, Stop the Integration Principle, 33 FordHAM INT'L L.J. 1533, 1545 (2010).

198. Ingolf Pernice, The Treaty of Lisbon: Multilevel Constitutionalism in Action, 15 Colum. J. EuR. L. 349, 354-355 (2009); Dirk Vandermeersch, The Single European Act and the Environmental Policy of the European Economic Community, 12 EUR. L. REV. 407, 427 (1987); Ludwig Kramer, The Single European Act and Environment Protection: Reflections on Several New Provisions in Community Law, 24 CoMmON MKT. L. ReV. 659 (1987). 
viewed as trade restrictions and obstacles to the single market. ${ }^{199}$ As a result, the European Communities based a majority of its environmental policy actions on the general power to approximate ${ }^{200}$ and harmonize ${ }^{201}$ national laws. In addition, since the early 1970s, the European Communities implemented six Environmental Action Programs (EAPs), which set the Union-wide agenda for environmental policy. ${ }^{202}$

Today, the protection of the environment is a primary goal of the European Union, and is recognized as a common principle among all Member States. ${ }^{203}$ Environmental protection is also included as a provision in the "Charter of Fundamental Rights of the European Union," which states that "[a] high level of environmental protection and the improvement of the quality of the environment must be integrated into the policies of the Union and ensured in accordance with the principle of sustainable development." 204

While the Treaty on the Functioning of the European Union today still lacks any specific definition of the term environment, the term may be interpreted broadly. ${ }^{205}$ The European Union has described the environment as the sum total of the factors "human beings, fauna and flora, soil, water, air, climate and the landscape, the inter-action between the factors mentioned in the first and second indents, material assets and the cultural heritage [of people], ${ }^{, 206}$ including their social environment. ${ }^{207}$

199. Council Directive 85/337, 1985 O.J. (L 175) 1 (EEC); EuGH Rs. 91/79, Detergentien, Slg. 1980, 1099 (1106); Rs.92/79, Schwefelhöchstgehalt, Slg. 1980, 1115 (1122); Eckhard RehBinder \& Richard Stewart, EnVtl. Prot. Pol'y 15-20 (1988); see also TFEU, supra note 187, art. 352.

200. TFEU, supra note 187 , art. 115 .

201. TFEU, supra note 187 , art. 352.

202. See, i.e., Don C. Smith, The European Union's Commitment to Sustainable Development: Is the Commitment Symbolic or Substantive in the Context of Transport Policy?, 13 CoLo. J. INT'L. ENVTL.. L. \& POL'Y 241, 249 (2002); Ian B. Bird \& Miguel A. Veiga-Pestana, European Community Environmental Policy and Law, in EUROPEAN UNION LAW after MaAstricht: A Practical Guide for LaWyers Outside the COMMON MARKET 219, 222, (Ralph B. Lake et al. eds., 1993) (stating that Environmental Action Programs spurred European community environmental legislation).

203. See, e.g., Case C-321/95, Greenpeace v. Comm'n, 1998 E.C.R. I-1702, I-1711.

204. Charter of Fundamental Rights of the European Union, art. 37, Dec. 18, 2000, 2000 O.J. (C 303), archived at http://perma.cc/8FE-4TYP.

205. See, e.g., ASTRID EPINEY, EUROPÄISCHES UNIONSRECHT: EUV, AEUV, GRUNDRECHTE-CHARTA art. 191, ๆ 3 (Christoph Vedder \& Wolff Heintschel von Heinegg eds., 2012); ASTRID EPINEY, UMWELTRECHT IN DER EUROPÄISCHEN UNION. PRIMÄRRECHTLICHE GRUNDLAGEN - GEMEINSCHAFTLICHES SEKUNDÄRRECHT 3 (2d ed. 2005); SiEgFrIEd BREIER, EU- UND EG VERTRAG: KOMMENTAR ZU DEM VERTRAG ÜBER DIE EUROPÄISCHE UNION UND ZU DEM VERTRAG DER GRÖNDUNG DER EUROPÄISCHEN GEMEINSCHAFT art. 174, 9 IT 4-7 (4th ed. 2006).

206. Council Directive 85/337, supra note 199, art. 3 (alteration added).

207. TFEU, supra note 187 , art. 191(3). 


\section{The Role of Environmental Action Programs}

The Environmental Action Programs (EAPs) fulfill an important role in the environmental decision-making process of the European Union. The programs are enacted for three to ten years and function as a general guideline by identifying specific goals for Union-wide actions and developing specific environmental policies for the duration of the program. ${ }^{208}$

The fifth ${ }^{209}$ and $\operatorname{sixth}^{210}$ EAPs are the most relevant to hydraulic fracturing of shale gas. The fifth EAP set long-term objectives towards the sustainability of and access to natural resources during the $1990 \mathrm{~s} .{ }^{211}$ It also established the principle that effective environmental protection at the European Union level can only be achieved if the environmental impact is considered in all policy areas, including the energy sector. ${ }^{212}$ In particular, the fifth EAP identified European Union energy policy as an important environmental objective, ${ }^{213}$ calling for regulatory actions to address climate change, improve water resource management, and protect biodiversity. ${ }^{214}$

The most recent action program is the sixth $\mathrm{EAP},{ }^{215}$ which will be replaced by a new program by the end of $2013 .{ }^{216}$ The sixth EAP has been

208. See, e.g., Decision No. 1600, art. 1 (3), 2002 O.J. (L 242)) [hereinafter 6th EAP] (stating that "The Programme shall cover a period of ten years starting from 22 July 2002. Appropriate initiatives in the different policy areas with the aim of meeting the objectives shall consist of a range of measures including legislation and the strategic approaches outlined in Article 3. These initiatives should be presented progressively and at the latest by four years after the adoption of this Decision"), archived at http://perma.cc/TE4T-QNWP.

209. European Commission, Towards Sustainability, A European Community Programme of Policy and Action in Relation to the Environment and Sustainable Development, OJ C 138/5 (May 17, 1993) [hereinafter 5th EAP], archived at http://perma.cc/D5XS-Y2HD.

210. See, 6th EAP, supra note 208.

211. See, e.g., 5th EAP, supra note 209, at 21; see also, Decision 2179/98 of the European Parliament and of the Council of 24 September 1998 on the Review of the European Community Programme of Policy and Action in Relation to the Environment and Sustainable Development, art. 2, 2179/98/EC, 1998 O.J. (L 275) 1.

212. Id.; 5th EAP, supra note 209, at 14-15; see also, The Amsterdam Treaty, supra note 195, art. 6; TFEU, supra note 187 , art 11.

213. 5th EAP, supra note 209, at 14-15; see also, Communication from the Commission, The Global Assessment of the European Community Programme of Policy and Action in Relation to the Environment and Sustainable Development, 'Towards Sustainability', COM/99/0543 final (Nov. 24, 1999), Objective (2) 5 [hereinafter Commission Communication], archived at http://perma.cc/3E5P-BDLX.

214. 5th EAP, supra note 209, at 24 et seq.; see also, Commission Communication, supra note 213, ๆ 3.3 .

215. 6th EAP, supra note 208, art. 1(3).

216. Proposal for a New EU Environment Action Programme to 2020, EUR. COMM'N, http://ec.europa.eu/environment/newprg/7eap.htm (last updated Jan. 17, 2014, archived at http://perma.cc/G4NC-NL8B); Press Release, Commission Wants Your Views on Priority 
the basis for environmental policy decisions by the European Union since $2002 .{ }^{217}$ The program continues the agenda of the fifth EAP, and remains focused on climate change, greenhouse gas emissions, natural resources, and waste management. ${ }^{218}$ With respect to the energy sector, the program aims at increasing energy efficiency and the use of renewable energy sources, while also reducing methane emissions during energy production. $^{219}$

\section{The Legislative Power to Enact Environmental Laws}

The Treaty on the Functioning of the European Union (the Treaty or TFEU) also defines objectives of European Union environmental policy. Specifically, article 191 of the TFEU outlines five main objectives as the basis for environmental legislative actions at the Union level. The objectives are: (1) preserving, protecting and improving the quality of the environment; (2) protecting human health; (3) utilizing natural resources in a prudent and rational manner; (4) promoting environmental policies at the international level to deal with regional or worldwide environmental problems; and (5) combating climate change. ${ }^{220}$ The implementation of these objectives may be achieved through two different decision-making procedures at the Union level. Depending on the impact a specific Union measure may have on Member States, legislative actions may be based on the "ordinary" 221 or the "special" decision-making procedure of the Treaty. 222

The "ordinary" procedure is the default procedure by which the Union takes environmental policy actions. ${ }^{223}$ After a proposal by the Commission and consultation with the Economic and Social Committee and the Committee of the Regions, legislation can only be enacted if the European Parliament and Council work together and agree on a common proposal. ${ }^{224}$ If the Parliament and the Council do not agree, the act fails. ${ }^{225}$

Objectives for the Environment, European Commission (Mar. 30, 2012, archived at http://perma.cc/G6V9-UVB4); Janez Potocnik, Speech at the High Level IEEP (Institute for European Environment Policy) Conference on the Future of EU Environmental Policy, Living Well, Within the Limits of the Planet, EUR. COMM'N (Dec. 4, 2012, archived at $\mathrm{http}: / /$ perma.cc/S6PE-46R8).

217. 6th EAP, supra note 208, art. 1(3); see also Communication from the Commission to the European Parliament, The Council, The European Economic and Social Committee and the Committee of the Regions, at 2, COM (2011) 531 Final (Aug. 31, 2011, archived at http://perma.cc/52FL-VS4W).

218. 6th EAP, supra note 208, art 2(2).

219. 6th EAP, supra note 208 , art. 5.

220. TFEU, supra note 187, art. 191(1).

221. TFEU, supra note 187 , art. 294.

222. TFEU, supra note 187 , art. 289(2).

223. TFEU, supra note 187 , art. 192(1).

224. TFEU, supra note 187, arts. 192(1), 294.

225. TFEU, supra note 187, arts. 294(7)(b), 294(12). 
The second legislative decision-making procedure is the "special" decision-making procedure. This procedure only requires that the Council consult the European Parliament, the Economic and Social Committee, and the Committee of the Regions. ${ }^{226}$ The Council makes the final decision with or without the European Parliament's consent. ${ }^{227}$ Decisions under the "special" decision-making procedure only require a unanimous vote by the Council, which effectively guarantees that Member State have control over the passage of legislation. ${ }^{28}$ Any Member State that disagrees with a proposal is thus able to block legislation, making the enactment of Union law difficult if national interests are implicated. ${ }^{229}$

Legislative acts that are subject to the TFEU's "special" or consultation procedure include measures that affect town and country planning, the quantitative management of water, certain types of land use, and a Member State's choice between energy sources and supply. ${ }^{230}$

Environmental concerns regarding hydraulic fracturing include quantitative water management and more generally relate to questions of energy sources and supply. As a result, many issues related to hydraulic gas fracturing in Europe may require two different legislative procedures, discussed above, and be heavily influenced by national self-interests. This in turn may not only prevent the enactment of a comprehensive and effective Union-wide framework addressing all environmental concerns related to fracturing, it may also threaten the achievement of the environmental protection objectives the Member States set for the European Union. ${ }^{231}$

\section{B. Energy Policy in the European Union}

Since the Founding Treaties, energy policy has been an essential part of European economic integration. ${ }^{232}$ In particular, energy policy was a

226. TFEU, supra note 187 , art. 192(2); see also TFEU, supra note 187 , arts. 19(1), 21(3), 48(7), 64(3), 113, 115, 127(6), 223, 289(2), 311, 312(2).

227. TFEU, supra note 187 , art. 293(1).

228. TFEU, supra note 187, art. 293(1).

229. TFEU, supra note 187, art. 293(1). The Council may, however, acting on a proposal by the Commission, unanimously decide that even these matters should be decided by way of the ordinary legislative procedure. TFEU, supra note 187, art. 293(1).

230. TFEU, supra note 187 , art. 192(2).

231. See generally TFEU, supra note 187, art. 3(2). (stating that "[The Union] shall work for the sustainable development of Europe based on . . . a high level of protection and improvement of the quality of the environment.") (alteration added).

232. SEbastian SCHULENBERG, Die ENERGIEPOLITIK DER EUROPÄISCHEN UNION: EINE KOMPETENZRECHTLICHE UNTERSUCHUNG UNTER BESONDERER BERÜCKSICHTIGUNG FINALER KOMPETENZNORMEN17-23 (Nomos ed. 2009). 
main focus of the European Coal and Steel Community (ECSC) $)^{233}$ and the Euratom Treaty, ${ }^{234}$ providing "for a common policy with specific energy policy tools based on exclusive supranational powers vested in a central authority." 235 In addition, the Maastricht Treaty added "measures in the sphere[] of energy"236 to the European Union's task to establish a common market by implementing common policies. ${ }^{237}$ Yet, the Member States failed to agree on a more explicit power to implement Union-wide energy policies until the Treaty of Lisbon. ${ }^{238}$ In fact, before the ratification of the Treaty of Lisbon, the primary basis for energy policy legislation was the Union's power to ensure the "establishment and functioning of the internal market" ${ }^{239}$ and creation of environmental protection laws. ${ }^{240}$ The Treaty of Lisbon appears to change this by adding a new chapter on energy to the TFEU and making energy policy a part of European Union primary law for the first time. ${ }^{241}$ Thus, along with environmental policy, energy policy is now a shared power between the European Union and its Member States. ${ }^{242}$

\section{The New Chapter on Energy, TFEU, Article 194}

Article 194 of the TFEU defines the four main objectives of European

233. Treaty Establishing the European Coal and Steel Community, Apr. 18, 1951, 261 U.N.T.S. 140 (expired by its terms July 23, 2002), archived at http://perma.cc/QC2A-S2SS.

234. Treaty Establishing the European Atomic Energy Community, Mar. 25, 1957, 298 U.N.T.S. 259, 5 Eur. Y.B. 454, archived at http://perma.cc/W6UE-R73Z.

235. Sami andoura, et al., Towards a European Energy Community: A Policy PROPOSAL ii (2010), archived at $\mathrm{http}: / /$ perma.cc/3AKJ-BASX.

236. Maastricht Treaty, supra note 194 (alteration added).

237. Maastricht Treaty, supra note 194, art. 2.

238. Treaty of Lisbon Amending the Treaty on European Union and the Treaty Establishing the European Communities, Dec. 13, 2007, 2007 O.J. (C 306) 1; but see JAN Frederick Braun, EU Energy Policy Under the Treaty of Lisbon: Between a New POLICY AND BUSINESS AS UsUAL 8 (2011), archived at http://perma.cc/L48H-VCKJ; see also WOLFGANG KAHL, DIE KOMPETENZEN DER EU IN DER ENERGIEPOLITIK NACH LISSABON [THE POWERS OF THE EU IN ENERGY POLICY AFTER Lisbon], VOL. 5 EUROPARECHT (EUR) 601, 604 (2009).

239. See, e.g., TFEU, supra note 187, art. 114(1); see also MICHAEL RODI, EUROPÄISCHES UNIONSRECHT: EUV, AEUV, GRUNDRECHTE-CHARTA art. 194, fT 1-3 (Christoph Vedder \& Wolff Heintschel von Heinegg eds., 2012); WOLFGANG KAHL, EUV/EGV VERTRAG ÜBER DIE EUROPÄISCHE UNION UND VERTRAG ZUR GRÜNDUNG DER EUROPÄISCHEN GEMEINSCHAFT art. 175 \ 28-29 (Rudolf Streinz ed., 2003).

240. Single European Act, supra note 192, art. 130r(4). See EUROPEAN COMM'N, THE European Climate Change Programme: EU Action Against Climate Change 5 (2006), archived at $\mathrm{http}: / /$ perma.cc/AK8Y-FFN2 (giving a summary of the European Union Climate Change Program).

241. Energy, EUROPA, http://europa.eu/legislation_summaries/institutional_affairs/ treaties/lisbon_treaty/ai0024_en.htm (last updated Apr. 19, 2010, archived at $\mathrm{http}: / /$ perma.cc/U7X-GJ6G).

242. TFEU, supra note 187 , art. 4(i). 
energy policy as: (1) ensuring the functioning of the energy market; (2) ensuring the security of the energy supply; (3) promoting energy efficiency, energy savings, and the development of new and renewable forms of energy; and (4) promoting the interconnection of energy networks. ${ }^{243}$ The implementation of these objectives is defined "[i]n the context of the establishment and functioning of the internal market and with regard for the need to preserve and improve the environment."244

Despite the inclusion of this new chapter on energy, the wording of article 194 seems to reinforce nothing more than the existing legislative trend in the EU and underscores that energy policy is only a horizontal Union policy, which does not exist in a vacuum. The inclusion of energy policy in a new chapter of the TFEU may therefore serve only to confirm and memorialize the already existing status-quo of European Union actions in the area of energy policy. ${ }^{245}$ Nevertheless, one benefit may be the fact that European energy policy must now be decided by default through the "ordinary" legislative procedure, requiring the cooperation of the European Parliament. ${ }^{246}$ Energy legislation that is "primarily of a fiscal nature"247 must be adopted based on the "special" legislative procedure and requires Member State consent. ${ }^{248}$ Overall, this change to the decision-making procedure in the area of energy policy may limit national self-interests when the European Union enacts measures relating to hydraulic fracturing.

\section{Environmental and Energy Policy as Competing Powers}

Environmental protection and energy policy are unavoidably overlapping policy areas. For example, while climate change and the protection of natural resources are key environmental concerns, the exploration and production of natural gas through hydraulic fracturing undoubtedly relates to the issue of energy supply and independence. Yet,

243. TFEU, supra note 187 , art. 194(1).

244. TFEU, supra note 187, art. 194(1).

245. See, e.g., Energy, supra note 241.

246. TFEU, supra note 187, art. 194(2).

247. TFEU, supra note 187 , art. 194(3).

248. TFEU, supra note 187, art. 194(3). It is important to note that the reservation of Member States' national interests may always be greater in the energy sector when compared to environmental protection. Energy policy is not only more closely related to fiscal matters, but also national sovereignty. This conclusion is also evident when comparing the wording of article 194 with article 192 of the TFEU. Article 192 grants the European Union the power to take actions for the protection of the environment and allows decisionmaking based on the "special" legislative procedure. More importantly, the wording of article 192 requires that measures on energy sources and supply "significantly" affect Member States' choices. See TFEU, supra note 187, art. 192(2)(c). In contract, article 194(3) sets a much lower standard when requiring that a measure is "primarily" of a certain nature. See TFEU, supra note 187, art. 194(3); see also, RoDI, supra note 239, art. 194, ๆf 13-14. 
the exploration of shale gas is also associated with major environmental concerns such as air pollution, drinking water depletion, contamination and land use. It is unclear which of these two policy areas and respective Union powers should function as the appropriate legal basis for any specific Union measure involving hydraulic fracturing. This regulatory uncertainty is compounded by the fact that European Union measures in the area of energy policy, for at least two decades, have also been based on the European Union's powers to enact environmental protection laws. ${ }^{249}$ Furthermore, since the implementation of the Treaty of Amsterdam, "environmental protection requirements" ${ }^{250}$ must always "be integrated into the definition and implementation of ${ }^{251}$ all Union policies, including energy. ${ }^{252}$

Choosing the appropriate legal basis for a European Union measure is significant for many reasons. The choice not only determines which decision-making procedure applies, but ultimately also determines to what extent Member States can get involved or whether Member States may be able to block the enactment of a specific law. Choosing the appropriate legal basis also directly impacts the validity of a Union measure and the ability of the Commission to enforce these laws.

In early 2013, the General Court addressed this issue in Republic of Poland v. European Commission, ${ }^{253}$ holding that "the choice of the legal basis for a European Union measure must rest on objective factors which are amendable to judicial review, including in particular the purpose and the content of that measure." ${ }^{, 254}$ In Republic of Poland, Poland disputed certain emission trading allowances. ${ }^{255}$ A European Union directive ${ }^{256}$ established a specific scheme for emission allowance trading in order to reduce greenhouse gas emissions throughout the Union. ${ }^{257}$ Under the directive, the European Commission was given the responsibility to implement all necessary harmonizing measures, including the setting of benchmarks. ${ }^{258}$ The Commission chose natural gas as the reference benchmark for the

249. KAHL, supra note 238 , at 601,604 ; SCHULENBERG, supra note 232 , at $150-153$; see also RODI, supra note 239, art 194, ๆ| 2; KAHL, supra note 239, art. 175 ๆ 28-29.

250. TFEU, supra note 187 , art. 11.

251. TFEU, supra note 187, art. 11.

252. The Amsterdam Treaty, supra note 195, art. 3c; see also TFEU, supra note 187, art. 11.

253. Case T-370/11, Republic of Poland v. European Comm'n, 2013 EUR-Lex $62011 \mathrm{TJ} 0370$ (Mar. 7, 2013).

254. Id. $\mid 14$.

255. Id. ๆ 3-7.

256. Directive 2003/87, 2003 O.J. (L 275) (EC).

257. Case T-370/11, Republic of Poland v. European Comm'n, 2013 EUR-Lex $62011 \mathrm{TJ} 0370$ ๆ 1 (Mar. 7, 2013).

258. Directive 2003/87, supra note 256, art. 10a(1); see also Case T-370/11, Republic of Poland v. European Comm'n, 2013 EUR-Lex 62011 TJ0370 \& 2 (Mar. 7, 2013). 
emission trading. ${ }^{259}$ Poland contested this decision, challenging the legal basis of the directive and claiming that the Commission's decision to use natural gas as a benchmark was arbitrary and unjustified. ${ }^{260}$

Poland asserted that the Commission's decision did not take the country's specific circumstances into consideration, ${ }^{261}$ and would limit its sovereign right to determine the conditions for exploitation of its own energy resources. ${ }^{262}$ Poland further contended that the answer to the question of whether a specific Union measure is based on the correct legal basis should be determined by considering all provisions of the Treaty in tandem, including the provisions protecting Poland's sovereign rights in the area of energy ${ }^{263}$ According to Poland, it never explicitly transferred any power regarding energy exploitation or source selection to the European Union and therefore these sovereign rights cannot be preempted by the European Union. ${ }^{264}$

Poland also claimed that using natural gas as a reference benchmark would negatively impact the competitiveness of Polish companies using coal technology and over the long-term globally lead to an increase in greenhouse emissions. ${ }^{265}$ Poland argued that many businesses, rather than reducing emissions, would move their manufacturing facilities to other countries where regulations of greenhouse gases are less stringent. ${ }^{266}$ Finally, Poland also noted that Polish companies may be forced to purchase more gas technology, thereby increasing the overall need for natural gas in Poland, disrupting the country's energy balance and forcing it to change its energy policy. ${ }^{267}$

The General Court rejected all of Poland's arguments, holding that the directive regulating emission allowance trading was appropriately based on the European Union's power to enact environmental protection laws, and that the directive was focused on environmental policy rather than energy. ${ }^{268}$ The Court further noted that, regardless of any reservation of sovereign rights in the energy sector, no general principle would prohibit

259. Republic of Poland v. European Comm'n, 2013 EUR-Lex 62011TJ0370 | 9 (Mar. 7, 2013).

260. Id. ๆ 10.

261. Id. $\mid 9$.

262. Id. ๆ 10.

263. Id. ๆ 16.

264. Id.

265. Id.

266. Id.

267. Id.

268. Id. I 14 ("According to settled case-law, the choice of the legal basis for a European Union measure must rest on objective factors which are amenable to judicial review, including in particular the purpose and the content of that measure. In the present case, Directive 2003/87 was adopted on the sole legal basis of Article 175(1) EC and Article 10a of that directive is the only legal basis of the contested decision ..."). 
Member States from assigning that right to the European Union in the area of environmental policy. ${ }^{269}$ The Court went on to clearly distinguish between activities pertaining to environmental policy and those relating to energy policy. ${ }^{270}$ It noted that energy policy is only a "sectoral competence" of the European Union ${ }^{271}$ and acknowledged the independent and distinctive nature of environmental policy when compared to energy policy. ${ }^{272}$

In sum, the General Court recognized that energy and environmental policy overlap, but remain independent and distinctive powers at the same time. In addition, the Court emphasized that the Union is not precluded from regulating the energy sector through its environmental policy powers as long as the decision to do so rests on objective factors and is subject to judicial review. ${ }^{273}$

\section{REGULATORY APPROACH IN THE EUROPEAN UNION}

\section{A. Existing Regulatory Regime}

There are at least nineteen EU Directives and Regulations that are relevant to shale gas exploration. ${ }^{274}$ It is beyond the scope of this Article to discuss all of these acts and the applicable case law in more detail. ${ }^{275}$

269. Id. ๆ 17.

270. See id.

271. Id: see also Case C-490/10, European Parliament v. Council of the European Union, 2012 Eur-Lex 62010CC0490, $\{33$ (Apr. 18, 2012).

272. Republic of Poland v. European Comm'n, 2013 EUR-Lex 62011TJ0370 \ 17 (Mar. 7, 2013) ("Indeed, the second subparagraph [of] Article 194(2) TFEU provides that the prohibition on affecting the right of a Member State to determine the conditions for exploiting its energy resources, its choice between different energy sources and the general structure of its energy supply applies without prejudice to point (c) of the first subparagraph of Article 192(2) TFUE [sic]. While that latter provision is only procedural in nature, it nonetheless provides specific rules relating to the environmental policy of the European Union.").

273. See id. $\llbracket 14$.

274. Council Directive 2001/42, 2001 O.J. (L 197) (EC); Council Directive 2011/92, 2011 O.J. (L 26) 1 (EU) [hereinafter EIA Directive]; Council Directive 2008/1, 2008 O.J. (L 24) (EC); Council Directive 2010/75, 2010 O.J. (L 158) (EC); Council Directive 2006/21, 2006 O.J. (L 102) (EC); Council Directive 2004/35, 2004 O.J. (L 143) (EC); Council Directive 2008/98, 2008 O.J. (L 312) (EC); Council Directive 2000/60, 2000 O.J. (L 327) 1 (EC); Council Directive 2006/118, 2006 O.J. (L 372) 19 (EC); Council Directive 2002/49, 2002 O.J. (L 189) 12 (EC); Council Directive 2008/50, 2008 O.J. (L 152) 1 (EC); Council Directive 1992/43, 1992 O.J. (L 59) (EC); Council Directive, 2009/147, 2009 O.J. (L 20) 7 (EC); Council Directive 2008/98, 2008 O.J. (L 312) 3 (EC); Council Directive 98/8, 1998 O.J. (L 123) 1 (EC); Council Directive 94/22, 1994 O.J. (L 164) (EC); Council Directive 1996/82, 1996 O.J. (L 10) (EC); Council Directive 1992/29, 1992 O.J. (L 113) (Euratom); Council Directive 97/271, 1991 O.J. (L 135) (EC).

275. The authors are exploring the relevance and impact of the case law of the European Court of Justice on shale gas exploration in a separate article. 
Instead, this Article focuses on a few examples of these laws and how they may apply to the regulation of shale gas fracturing.

\section{Environmental Impact Assessments}

The Strategic Environmental Assessment (SEA) Directive, ${ }^{276}$ and the Environmental Impact Assessment (EIA) Directive, ${ }^{277}$ provide a two-tier legal framework for conducting environmental impact assessments. ${ }^{278}$ The EIA Directive may be considered the most important directive for shale gas fracturing. It ensures that environmental concerns are considered at the earliest stage of each fracturing project and well before a permit is issued. ${ }^{279}$ Further, it ensures public involvement during the permit issuing process. ${ }^{280}$

\section{a. Strategic Environmental Assessment}

The SEA Directive establishes a minimum requirement ${ }^{281}$ by which Member States provide an environmental assessment of all national plans and programs that may significantly impact the environment. ${ }^{282}$ The purpose of the SEA Directive is to provide national, regional, and local level regulatory authorities in all Member States with the necessary information to assess potential environmental risks and allow these authorities to consider them appropriately with the goal of achieving a high level of environmental protection. ${ }^{283}$ The directive specifically requires that an environmental assessment be carried out for programs and plans that involve activities related to energy, waste management, water management, and land use. ${ }^{284}$ The Member States are required to prepare reports in which the significant environmental effects and reasonable alternatives are identified, described, and evaluated. ${ }^{285}$ The reports need to include explicit information on the effect of any of these activities on biodiversity, human

276. See Directive 2001/42, supra note 274.

277. EIA Directive, 2011/92, supra note 274. In October 2012, the European Commission submitted an amendment proposal for the EIA. PROPOSAL FOR A DIRECTTVE OF THE EUROPEAN PARLIAMENT AND OF THE COUNCIL AMENDING DIRECTIVE 2011/92/EU ON THE assessment of the Effects of Certain Public and Private Projects on the ENVIRonMent, COM (2012) [hereinafter EIA Amendment Proposal].

278. Directive 2001/42, supra note 274, art. 3(1); EIA Directive 2011/92, supra note 274, art. 2(1).

279. See Commission Guidance Note, supra note 184.

280. Commission Guidance Note, supra note 184; see also EIA Directive 2011/92, supra note 274 , art. $6(2)$.

281. See, e.g., Directive 2001/42, supra note 274, recital (8).

282. Directive 2001/42, supra note 274, art. 1.

283. Directive 2001/42, supra note 274, recitals (6), (9).

284. Directive 2001/42, supra note 274 , art. 3(2)(a).

285. Directive 2001/42, supra note 274, art. 5. 
health, fauna, flora, soil, water, air, climate factors, and landscape. ${ }^{286}$ Though not mentioned explicitly, the SEA Directive may apply to hydraulic fracturing activities in Europe. ${ }^{287}$ As a result, any Member State regulatory authority could be required to carry out a strategic environmental assessment before the issuance of any shale gas exploration or production permits. ${ }^{288}$

\section{b. Environmental Impact Assessment}

The Environmental Impact Assessment (EIA) Directive ${ }^{289}$ focuses on Member States' environmental impact assessments for public and private projects $^{290}$ and contains the legal requirements to carry out such assessments. ${ }^{291}$ Member States are specifically required to ensure that before any regulatory permits are issued, "projects likely to have significant effects on the environment by virtue, inter alia, of their nature, size or location are made subject to a requirement for development consent and an [environmental] assessment with regard to their effects."292

The EIA Directive applies to projects that generally involve the execution of construction works or other installations or schemes, ${ }^{293}$ as well as "interventions in the natural surroundings and landscape including those involving the extraction of mineral resources." 294 Annexes I and II of the EIA Directive further qualify these definitions, ${ }^{295}$ but distinguish between projects that require an obligatory ${ }^{296}$ or a discretionary impact assessment. ${ }^{297}$ For example, under Annex I, an obligatory assessment is required for the "[e]xtraction of petroleum and natural gas for commercial purposes where the amount extracted exceeds 500 tonnes/day in the case of petroleum and 500[,]000 cubic metres/day in the case of gas.",298 For smaller extraction projects, including underground mining, ${ }^{299}$ deep drilling, ${ }^{300}$ or "surface industrial installations for the extraction of coal,

286. Directive 2001/42, supra note 274, Annex I(f).

287. See, e.g., AEA REPORT POTENTIAL RISKS, supra note 13, at 79.

288. AEA REPORT POTENTIAL RISKS, supra note 13, at 79.

289. EIA Directive, supra note 274.

290. EIA Directive, supra note 274, art. 1(1).

291. See EIA Directive, supra note 274 , art. 4.

292. EIA Directive, supra note 274, art. 2(1) (alteration added).

293. See EIA Directive, supra note 274, art. 1(2)(a).

294. EIA Directive, supra note 274, art. 1(2)(a).

295. EIA Directive, supra note 274, Annex I-II.

296. EIA Directive, supra note 274 , art. 4(1).

297. EIA Directive, supra note 274, art. 4(2).

298. EIA Directive, supra note 274, Annex I 14 (alterations added).

299. EIA Directive, supra note 274, Annex II ๆ 2(b).

300. EIA Directive, supra note 274, Annex II I 2(d). Deep drillings are defined as "(i) geothermal drilling; (ii) drilling for storage of nuclear waste material; (iii) drilling for water 
petroleum, natural gas and ores, as well as bituminous shale,",301 Annex II only requires a discretionary assessment. The same applies to industrial installations that carry gas ${ }^{302}$ or engage in the surface storage of natural gas $^{303}$ and fossil fuels. ${ }^{304}$

While the EIA Directive also lacks a direct reference to hydraulic shale gas fracturing, it is evident the Directive may apply to shale gas fracturing due to the environmental impacts of the fracturing process. ${ }^{305}$ In practice, the option to conduct a discretionary environmental impact assessment may result in fewer impact assessments from being carried out. Where Member States retain discretionary powers under the EIA Directive, the conduct of an impact assessment is determined on a case-by-case examination or through the setting of certain thresholds by each Member State. ${ }^{306}$ Member States ultimately retain the ability to make the final decision. ${ }^{307}$ The EIA Directive only requires Member States to take the characteristics, location, and potential impact of a project into account, and nothing more. ${ }^{308}$ The remaining discretion of the Member States thus leaves

supplies; with the exception of drillings for investigating the stability of the soil." EIA Directive, supra note 274, Annex II I 2(d).

301. EIA Directive, supra note 274, Annex II I| 2(e).

302. EIA Directive, supra note 274, Annex II ๆ 3(b).

303. EIA Directive, supra note 274, Annex II \3(c).

304. EIA Directive, supra note 274, Annex II II 3(e).

305. See, e.g., Minutes of the EIA and SEA National Experts Meeting, at 6 (Apr. 14-15, 2011), archived at http://perma.cc/TSQ5-Z338;

The EIA Directive is applicable to unconventional/shale gas activities. An EIA is mandatory for projects falling within Annex I.14 (extraction of natural gas where the amount of gas extracted exceeds $500.000 \mathrm{~m} 3$ per day). For projects below this threshold (e.g. those mentioned in Annex II.2.d or II.2.e), a screening is required, in accordance with Articles 2(1), 4(2)-(4) and Annex III of the EIA Directive. Projects related to exploration of unconventional/shale gas are also subject to the requirements of the EIA Directive. It should be recalled that Annex II.2.d refers to 'deep drillings'. The environmental effects of unconventional/shale gas projects are likely to be significantly negative (in particular on soil, water, air, climate and landscape). This is why the decision on whether an EIA is needed should also take into account the precautionary principle. Under this principle, shale gas production projects would be subject to an EIA if it cannot be excluded, on the basis of objective information, that the project will have significant environmental effects. The precautionary principle also implies that in case of doubts as to the absence of significant effects, an EIA must be carried out.

Id.; see also AEA REPORT POTENTIAL RISKS, supra note 13, at 81. Conversely, the European Parliament has noted that shale gas exploitation projects are not generally subject to an environmental impact assessment as mandated under the EIA. See Resolution on the Environmental Impacts of Shale Gas and Shale Oil Extraction Activities, EUR. PARL. DOC. A7-0283 Recital K (2012), archived at http://perma.cc/A9WQ-TUYD.

306. EIA Directive 2011/92/EU, supra note 274, art. 4(2).

307. EIA Directive 2011/92/EU, supra note 274, art. 4(2).

308. EIA Directive 2011/92/EU, supra note 274, art. 4(3). Annex III provides that 
ample room for political decision-making based on national preferences, protectionism, and industry lobbying. ${ }^{309}$ Member States that view fracturing as a high-risk activity may require environmental impact assessments, while other Member States that do not share similar views may not do so. This, in turn, may lead to significant legal uncertainty and regulatory differences between the Member States and mark the starting point of a regulatory race to the bottom in the European Union.

Based on information and data available from the US, specifically gas production in the Marcellus Shale in New York, a production rate of more than 250,000 cubic meters per day is unlikely for any well. ${ }^{310}$ Anything higher than this would seem even more unrealistic in Europe, since the overall production rate in Europe will most likely be lower than in the US. ${ }^{311}$ As a result, the threshold for a mandatory environmental impact assessment of 500,000 cubic meters per day under Annex I of the EIA Directive will be difficult to meet unless the total production rate of multiple wells is taken into account. ${ }^{312}$ The EIA Directive allows such a cumulative impact analysis only in the context of Member States' discretionary powers and when no mandatory assessment is otherwise required. ${ }^{313}$ This would once again seem to leave the ultimate decision over the conduct of an impact assessment and the application of a cumulative impact analysis to the Member States.

A recent Commission proposal aims at amending and updating the

[t]he characteristics of projects must be considered having regard, in particular, to: (a) the size of the project; (b) the cumulation with other projects; (c) the use of natural resources; (d) the production of waste; (e) pollution and nuisances; (f) the risk of accidents, having regard in particular to substances and technologies used... [t]he environmental sensitivity of geographical areas likely to be affected by projects must be considered, having regard, in particular, to: (a) the existing land use; (b) the relative abundance, quality and regenerative capacity of natural resources in the area; (c) the absorption capacity of the natural environment ... [t] he potential significant effects of projects must be considered in relation to criteria set out in points 1 and 2, and having regard in particular to: (a) the extent of the impact ... (b) the transfrontier nature of the impact; (c) the magnitude and complexity of the impact; (d) the probability of the impact; (e) the duration, frequency and reversibility of the impact.

Id.

309. See, e.g., Poland and Romania.

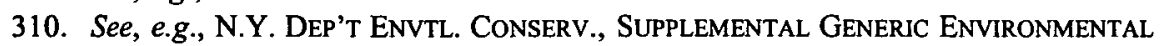
IMPACt Statement ON The OIL, Gas and SOlution MINING Regulatory Program; Well Permit Issuance for Horizontal Drilling ANd High-Volume Hydraulic Fracturing TO DEVELOP THE MARCELluS SHALE AND OTHER LOW-PERMEABILITY GAS RESERVOIRS 5-139 (2011), archived at http://perma.cc/9AUG-878F.

311. See, e.g., AEA REPORT POTENTIAL RISKS, supra note 13, at 80.

312. AEA REPORT POTENTIAL RISKS, supra note 13, at 80.

313. EIA Directive 2011/92/EU, supra note 274, Annex III, ๆ 1(b). 
ELA Directive. ${ }^{314}$ The proposal does not directly refer to or single out hydraulic fracturing, but includes a number of important changes that may require a mandatory impact assessment for hydraulic fracturing projects. Overall, the new proposal includes an improved assessment procedure allowing for better coordination and integration of impact concerns under the EIA. ${ }^{315}$ Specifically, a proposed mandatory ex-post monitoring requirement for industrial projects with significant adverse effects on the environment would also apply to hydraulic fracturing. ${ }^{316}$ Also relevant is a newly proposed power for the Commission. Through a delegated act, the Commission may be able to amend the selection criteria for future impact assessments without Member State consent, allowing for a quicker adaptation of the Directive's application to new technologies, such as hydraulic fracturing, and environmental concerns associated with these technologies. ${ }^{317}$ This power bears greater significance when viewed in conjunction with yet another proposed amendment of the existing selection criteria in the Annex. The proposal includes the addition of new criteria or "characteristics of projects" concerns, such as man-made risks related to new technologies. ${ }^{319}$ If the European Parliament and the Council adopt the Commission proposal to amend the current EIA Directive, hydraulic fracturing could become subject to a mandatory environmental impact assessment, thereby resulting in fewer or no regulatory gaps among the Member States.

\section{Water}

The Water Framework (WF) Directive ${ }^{320}$ and the Groundwater (GW) Directive $^{321}$ are the most important European Union laws dealing with water-related concerns and address the potential risk of water depletion and contamination from hydraulic fracturing. The main goal of the WF Directive is the promotion of sustainable water use and prevention and reduction of pollution of any surface, transitional, coastal, and ground

314. See Commission Proposal for a Directive of the European Parliament and of the Council Amending Directive 2011/92/EU on the Assessment of the Effects of Certain Public and Private Projects on the Environment, COM (2012) 628 final (Oct. 26, 2012).

315. See id. If 3 ("Article 2(3) is amended to introduce an EIA 'one-stop shop,' allowing the coordination or integration of assessment procedures under the EIA Directive and other EU legislation.").

316. Id.

317. See id. arts. 12, 12(a).

318. Id. art. 4(a)(3).

319. Id. recital (26).

320. See Directive 2000, Establishing a Framework for the Community Action in the Field of Water Policy, 2000 O.J. (L 327) [hereinafter WF Directive].

321. See Directive 2006/118/EC on the Protection of Groundwater against Pollution and Deterioration, 2006 O.J. (L 372/19) [hereinafter Groundwater Directive]. 
water. ${ }^{322}$ Each Member State is required to establish and implement various programs and national legislation that will allow the objectives of the WF Directive to be accomplished. ${ }^{323}$ While the WF Directive contains only general provisions for the protection of groundwater, the GW Directive defines specific standards to prevent and control groundwater pollution of any kind. ${ }^{324}$ Further water resource protection may be found under the Mining Waste Directive. ${ }^{325}$

\section{a. Water Depletion and Pollution}

Measures that control the abstraction and impoundment of fresh surface and groundwater are part of the WF Directive mandate. ${ }^{326}$ Any of these actions require prior authorization by the Member State authorities and may only be exempt if these actions do not have any significant impact on the water status. ${ }^{327}$ For surface waters, the WF Directive mandates the prevention of deterioration of these waters as well as their protection, enhancement, and restoration. ${ }^{328}$ The same applies to groundwater, but Member States are further required to limit the input of any pollutants and

322. WF Directive, supra note 320 , art. 1.

323. For the status of the implementation of these measures, see Report from the Commission to the European Parliament and the Council in Accordance with Article 18.3 of the Water Framework Directive 2000/60/EC on Programmes for Monitoring of Water Status, at 5 -6, COM (2009) 156 final (Apr. 1, 2009); see also Commission Staff Working Document Accompanying the Report from the Commission to the European Parliament and the Council in Accordance with Article 18.3 of the Water Framework Directive 2000/60/EC on Programmes for Monitoring of Water Status, at 16 - 51, SEC (2009) 415 (Apr. 1, 2009, archived at http://perma.cc/GY84-Q79R). The latest or third WF Directive implementation report by the Commission focuses on the river basin management plan. Report From the Commission to the European Parliament and the Council on the Implementation of the Water Framework Directive (2000/60/EC) River Basin Management Plans, COM (2012) 670 final (Nov. 14, 2012); see also Commission Staff Working Document European Overview (1/2) Accompanying the document, Report From The Commission To The European Parliament And The Council on the implementation of the Water Framework Directive (2000/60/EC) River Basin Management Plans, SWD 2012, 379 final, 1/30, available at http://ec.europa.eu/environment/water/waterframework/pdf/CWD-2012-379_EN-Voll.pdf; Commission Staff Working Document European Overview (1/2) Accompanying the Document Report From the Commission to the European Parliament and the Council on the Implementation of the Water Framework Directive (2000/60/EC) River Basin Management Plans, SWD (2012) 379 final (Nov. 14, 2012), available at http://ec.europa.eu/environment/water/water-framework/pdf/CWD-2012379_EN-Voll.pdf (second volume available at http://ec.europa.eu/environment/water/waterframework/pdf/CWD-2012-379_EN-Vol2.pdf).

324. Groundwater Directive, supra note 321, art. 1(1).

325. See generally Directive 2006/21/EC, on the Management of Waste from Extractive Industries and Amending Directive 2004/35/EC, 2006 O.J. (L 102) (Mar. 15, 2006) [hereinafter Mining Waste Directive].

326. WF Directive, supra note 320 , arts. $4-5,11$.

327. WF Directive, supra note 320, art. $11(3)(\mathrm{e})$.

328. WF Directive, supra note 320 , art. $4(1)(a)$. 
ensure a balance between abstraction and the recharge of groundwaters. ${ }^{329}$

Much of the effectiveness of the WF Directive depends on Member State actions, including the necessary implementation of national laws as well as the identification and designation of water bodies protected under the Directive. ${ }^{330}$ To prevent regulatory gaps throughout the Union, Member States were required to make the Directive operational no later than the end of 2012. ${ }^{331}$ While the Commission provides updates on the implementation progress of the Directive, ${ }^{332}$ it remains questionable whether the implementation mandate is truly adequate to address water depletion risk in general, particularly, with regard to hydraulic fracturing. ${ }^{333}$ Even if the Commission finds that a Member State has incorrectly implemented the WF Directive, the only available enforcement mechanism may be to initiate an infringement procedure ${ }^{334}$ against a violating Member State. ${ }^{335}$ The infringement procedure is time consuming and not always very effective. ${ }^{336}$

The GW Directive includes more specific measures to address potential groundwater pollution when compared to the WF Directive. The former specifically incorporates standards for a body of groundwater considered to be "of good chemical status." "337 The GW Directive also defines measures that need to be taken to prevent or limit inputs of pollutants into the groundwater. ${ }^{338}$ At the same time, the Groundwater Directive only establishes a general requirement for Member States relating to the monitoring and protection of groundwater. ${ }^{339}$ As such, the GW Directive does not directly apply to hydraulic fracturing installations, but may be indirectly applicable. ${ }^{340}$ For example, the GW Directive may allow Member States to implement measures to limit the input of pollutants into

329. WF Directive, supra note 320, art. 4(b).

330. See, e.g., WF Directive, supra note 320, Annex I-II. Member States not only must designate the competent authorities, but also identify the location and boundaries of bodies of surface waters and carry out an initial characterization of all such bodies according to the mandate of the WFD. WF Directive, supra note 320, Annex I-II. For groundwater, the Member States must assess their uses and the degree to which they are at risk of failing the objectives set in the WF Directive. WF Directive, supra note 320, Annex I-II.

331. WF Directive, supra note 320, art. 11(7) ("The programmes of measures shall be established at the latest nine years after the date of entry into force of this Directive and all the measures shall be made operational at the latest 12 years after that date.").

332. WF Directive, supra note 320 , art. 18.

333. See, e.g., AEA REPORT POTENTIAL RISKS, supra note 13, at 104.

334. See, e.g., TFEU, supra note 187, art. 258.

335. See, e.g., Press Release, European Comm'n, Env't: Comm'n Takes Poland to Court over Water Legislation (Feb. 21, 2013), archived at http://perma.cc/W7XB-SFCZ.

336. See, e.g., Brian Jack, Enforcing Member State Compliance with EU Environmental Law: A Critical Evaluation of the Use of Financial Penalties, 23 J ENVTL. LAW 73 (2011).

337. Groundwater Directive, supra note 321, art. 4(2).

338. Groundwater Directive, supra note 321, art. 6.

339. AEA REPORT POTENTIAL RISKS, supra note 13, at 108.

340. AEA REPORT POTENTIAL RISKS, supra note 13, at 108. 
the groundwater that would occur as a result of shale gas exploration or a well bore leakage. ${ }^{341}$ But before such a determination could be made, however, a Member State would also have to establish that the wastewater is indeed a pollutant under the Directive.

\section{b. Wastewater Treatment}

The Mining Waste (MW) Directive $\mathrm{e}^{342}$ may also apply to hydraulic fracturing and cover the discharge of wastewater, flowback to surface waters, or injection of wastewater underground. ${ }^{343}$ Underground injections can result in polluted groundwater and contaminated aquifers. ${ }^{344}$ This Directive only applies to hydraulic fracturing, if the water from the hydraulic fracturing process is designated as a mining waste. Mining waste is defined broadly as any substance or object discharged or intended to be discharged by the operator of a mining facility. ${ }^{345}$ The applicability of the MW Directive to shale gas may also be triggered by the Directive's definition of mineral resources. Mineral resources, like shale gas, are defined as naturally occurring deposits. ${ }^{346}$

The MW Directive mandates that operators of extraction facilities take all necessary measures to avoid endangering human health or harming the environment ${ }^{347}$ Specifically, operators are obligated to draw up detailed waste management plans, among other things, to identify the categories of waste produced and the manner in which the operator will manage that waste. ${ }^{348}$ The submission of the management plan is a prerequisite for any operating permit ${ }^{349}$ and such a plan may need to include a major accident prevention policy as well as an internal emergency plan. ${ }^{350}$

Operators are required to submit waste management plans; however, they are only required to draw up major accident prevention policy and emergency plans if the waste facility proposed by the operator meets certain

341. AEA REPORT POTENTIAL RISKS, supra note 13, at 109.

342. Mining Waste Directive, supra note 325.

343. Mining Waste Directive, supra note 325, art. 1.

344. See supra Part II.B.1.a.

345. See Directive 2008/98, supra note 274. Directive 2008/98 amended Directive 75/442/EEC. The latter is referenced in art. 3(1) of the Mining Waste Water Directive as the basis for the definition of waste. See Commission Decision of 3 May 2000 Replacing Decision 94/3/EC Establishing a List of Wastes Pursuant to Article 1(a) of Council Directive 75/442/EEC on Waste and Council Decision 94/904/EC Establishing a List of Hazardous Waste Pursuant to Article 1(4) of Council Directive 91/689/EEC on Hazardous Waste, 2000 O.J. (L 226), at Index (Sept. 6, 2000) (classifying "drilling muds and other drilling wastes" as a hazardous waste category).

346. Mining Waste Directive, supra note 325, art. 3(5).

347. Mining Waste Directive, supra note 325, art. 4(1).

348. Mining Waste Directive, supra note 325, art. 5.

349. Mining Waste Directive, supra note 325, art. 7.

350. Mining Waste Directive, supra note 325 , art. 5(3)(a). 
risk thresholds, such as size, location, and potential environmental impact. ${ }^{351}$ The Directive does not include any clear guidance for risk assessments on which the Member States could rely to determine these thresholds. ${ }^{352}$ This draws into question which standard should be applied to determine the potential adverse effects on human health and the environment from the potential waste produced by hydraulic fracturing. ${ }^{353}$ The outcome is that each Member State may apply its own standards, resulting in another opportunity for regulatory arbitrage across the Union.

\section{Air}

At least three different European Union directives provide the legal framework for managing the impact of emissions to air during hydraulic fracturing. These directives are the Integrated Pollution Prevention and Control (IPPC) Directive, ${ }^{354}$ the Industrial Emissions Directive, ${ }^{355}$ and the Air Quality Directive. ${ }^{356}$

\section{a. Integrated Pollution Control}

The IPPC Directive covers permits for the energy, metal, mineral, chemical, and waste management industries. ${ }^{357}$ The directive is in force until January 2014, and will be replaced by the Industrial Emissions (IE) Directive. ${ }^{358}$

The IPPC Directive requires the issuance of a national integrated permit for all new ${ }^{359}$ or existing ${ }^{360}$ industrial activities with high pollution potential. The Directive provides measures to prevent and reduce emissions in the air, water, and land from these industrial activities. ${ }^{361}$ While the Directive does not explicitly mention shale gas exploration or hydraulic fracturing, it may apply to related activities, such as drilling. ${ }^{362}$ The

351. Mining Waste Directive, supra note 325, Annex III.

352. See AEA REPORT POTENTIAL RISKS, supra note 13, at 92.

353. AEA REPORT POTENTIAL RIsKS, supra note 13, at 92.

354. Directive 2008/1/EC concerning integrated pollution prevention and control, 2008

O.J. (L 24) [hereinafter IPPC Directive], archived at

http://eur-lex.europa.eu/LexUriServ/LexUriServ.do?uri=CELEX:32008L0001:en:NOT.

355. Directive 2010/75/EU, On Industrial Emissions (Integrated Pollution Prevention and Control), 2010 O.J. (L 334/17) [hereinafter IE Directive].

356. Directive 2008/50/EC, On Ambient Air Quality and Cleaner Air for Europe, 2008

O.J. (L 152/1) [hereinafter AQ Directive].

357. IPPC Directive, supra note 354.

358. See IE Directive, supra note 355, Recital 1.

359. IPPC Directive, supra note 354, art. 4.

360. IPPC Directive, supra note 354, art. 5.

361. IPPC Directive, supra note 354, art. 1.

362. IPPC Directive, supra note 354, art. 2(3) (defining an installation as "a stationary technical unit where one or more activities listed in Annex I are carried out, and any other 
Directive does not cover any specific installation or the main purpose of any activity. ${ }^{363}$ Rather, the Directive broadly focuses on activities that directly or indirectly introduce substances, vibrations, heat, or noise into the air, water, or land, that are harmful to human health or the environment. ${ }^{364}$

At most, the IPPC Directive is only relevant for two activities related to shale gas exploration. One of the activities includes "[c]ombustion installations with a rated thermal input exceeding $50 \mathrm{MW} .{ }^{365}$ Flaring, which introduces heat and noise into the air as part of the fracturing procedure, ${ }^{366}$ is not per se a combustion installation as defined by the Directive. As a result, only emissions from the diesel engines of drilling rigs may be covered. At the same time, it is uncertain whether a single drilling rig could exceed the Directive's $50 \mathrm{MW}$ thermal input threshold. Based on US comparisons, the maximum thermal input of a standard 5,400 horsepower engine may reach no more than $8 \mathrm{MW}{ }^{367}$ As a result, the threshold set by the IPPC Directive to drilling rigs may require adding multiple installations and activities together. ${ }^{368}$ While the Directive may allow for such an overall assessment of activities, ${ }^{369}$ a well operator may always be able to limit the actual number of drilling rigs used, thereby manipulating and preventing its applicability.

The second activity covered by the IPPC Directive, which is relevant to shale gas exploration, is waste management. ${ }^{370}$ Together with the Waste Framework Directive, ${ }^{371}$ the IPPC applies to activities that produce hazardous waste, including explosive, highly flammable, irritant, harmful, toxic, carcinogenic, corrosive, mutagenic, and any other waste being capable of yielding, after its disposal, any other substance, possessing

directly associated activities which have a technical connection with the activities carried out on that site and which could have an effect on emissions and pollution.").

363. See, e.g., AEA REPORT POTENTIAL RISKS, supra note 13, at 88.

364. IPPC Directive, supra note 354 , art. 2(2).

365. IPPC Directive, supra note 354, Annex I(1.1) (alteration added).

366. See, e.g., AEA REPORT POTENTIAL RISKS, supra note 13, at viii ("[f]laring of gas can also be noisy. For an individual well the time span of the drilling phase will be quite short (around four weeks in duration) but will be continuous 24 hours a day. The effect of noise on local residents and wildlife will be significantly higher where multiple wells are drilled in a single pad, which typically lasts over a five-month period.")(alteration added); see also AEA REPORT POTENTIAL RISKS, supra note 13, at 64 ("[f]laring may result in emission to air of combustion gases, and of some unburnt hydrocarbons, depending on the efficiency of the flaring process.") (alteration added).

367. See, e.g., N.Y. STATE DEP'T. OF EVNTL. CONSERV., supra note 109, at 6-99 to 6-100.

368. N.Y. STATE DEP'T. OF EVNTL. CONSERV., supra note 109, at 6-100.

369. IPPC Directive, supra note 354 , Annex I, 2 (stating that " $[w]$ here one operator carries out several activities falling under the same subheading in the same installation or on the same site, the capacities of such activities are added together.") (alteration added).

370. IPPC Directive, supra note 354, Annex I, 5.

371. Directive 2008/98, supra note 274; cf. IPPC Directive, supra note 354, Annex I (5.1) (which refers to article 1(4) of Directive 91/689/EEC, which was amended by Directive 2008/98). 
similar characteristics. ${ }^{372}$ Hydraulic fracturing fluids are widely understood to include compounds that are known to be carcinogens and otherwise hazardous to human health ${ }^{373}$ and may thus qualify as hazardous waste under the IPPC.

The new Industrial Emissions (IE) Directive, which will replace the IPPC in $2014,{ }^{374}$ does not include significant changes when compared to the IPPC Directive. ${ }^{375}$ The IE Directive will only apply to new installation permits and establishes better inspection ${ }^{376}$ and monitoring systems. ${ }^{377}$

\section{b. Air Quality}

The Air Quality (AQ) Directive aims at combating the emissions of pollutants in Europe. ${ }^{378}$ The Directive specifically provides limited values and alert thresholds to improve ambient air quality. ${ }^{379}$ It also establishes air quality standards to reduce harmful effects on human health and the environment as a whole. ${ }^{380}$ The Directive does not refer to any specific emission source, but instead more broadly refers to air quality and the harmful effects that may result from pollutants and poor air quality. ${ }^{381}$ Ambient air is defined as "outdoor air in the troposphere" 382 and pollutants are listed as "any substance present in ambient air and likely to have

372. See IPPC Directive, supra note 354, Annex I(5.1); Directive 2008/98, supra note 274, Annex III.

373. See, e.g., Minority Staff OF U.S. HOUSE OF RePresentatives COMM. ON ENERgY and Commerce, Chemicals Used IN Hydraulic Fracturing 1 (2011), archived at http://perma.cc/49CQ-9H5S ("[b]etween 2005 and 2009, the oil and gas service companies used hydraulic fracturing products containing 29 chemicals that are (1) known or possible human carcinogens, (2) regulated under the Safe Drinking Water Act for their risks to human health, or (3) listed as hazardous air pollutants under the Clean Air Act. These 29 chemicals were components of more than 650 different products used in hydraulic fracturing.") (alteration added).

374. IE Directive, supra note 355.

375. See, e.g., AEA REPORT POTENTIAL Risks, supra note 13, at 89.

376. IE Directive, supra note 355, art. 23, 1 ("Member States shall set up a system of environmental inspections of installations addressing the examination of the full range of relevant environmental effects from the installations concerned.").

377. The directive will introduce the requirement of a baseline report in order to better monitor a potential deterioration of the quality of the soil and groundwater at an installation. The report may include existing and historical measurement data to allow for a quantified comparison between the state of the site at the beginning of the installation and upon cessation of activities. IE Directive, supra note 355, at preamble recital 24-25; IE Directive, supra note 355, arts. 3(19), 12(e), 22.

378. AQ Directive, supra note 356, preamble recital 2.

379. See AQ Directive, supra note 356 , art. 1.

380. AQ Directive, supra note 356, art. 1.

381. See generally AQ Directive, supra note 356.

382. AQ Directive, supra note 356 , art. 2(1). 
harmful effects on human health and/or the environment.",383

Harmful emission from hydraulic fracturing covered by the AQ Directive could originate from the operation of diesel engines during well operation, processing of gas, evaporation of chemicals from wastewater ponds, and from spills or well blow-outs. ${ }^{384}$ In addition, the emission of methane, a greenhouse gas, may occur during production. ${ }^{385}$

The AQ Directive does not directly mention hydraulic fracturing, but it requires all Member States to reduce the concentration of fine particles in the air and meet the defined air quality standards. ${ }^{386}$ To achieve these objectives, the Member States must implement abatement measures, ${ }^{387}$ air quality ${ }^{388}$ and other short-term action plans. ${ }^{389}$ For example, emissions from stationary sources, vehicles, and transport must be reduced if they exceed the defined limit values. ${ }^{390}$ Because the well pad and site of a hydraulic fracturing installation may qualify not only as a stationary source, but also produce air emissions from vehicular or other transport sources, any such emission impacting particle and air quality levels will be covered under the AQ Directive. Additional abatement measures would be required and included in any fracturing permit issued by the Member States. ${ }^{391}$ And so, the AQ Directive, at least indirectly, applies to hydraulic fracturing as a potential emission source under the Directive.

\section{Impact on Land}

Land acquisition as well as the potential pollution of soil, fauna, and flora are the most obvious impacts on land from hydraulic fracturing. ${ }^{392} \mathrm{~A}$ shale gas pad may take up to 60 percent more space compared to conventional drilling. ${ }^{393}$ Multi-well pads can amplify this impact further, particularly if a shale gas formation is to be fully exploited. ${ }^{394}$

383. AQ Directive, supra note 356, art. 2(2).

384. European Parliament, Impacts of Shale Gas and Shale Oll Extraction on THE ENVIRONMENT AND ON HUMAN HEALTH 22 (2011).

385. Id.

386. AQ Directive, supra note 356, art. 14; see also Press Release, European Comm'n, Env't: Comm'n Welcomes Final Adoption of the Air Quality Directive, (Apr. 14, 2008), archived at http://perma.cc/LQ5H-6XNM.

387. AQ Directive, supra note 356 , preamble recital 16 , Annex XV B(3).

388. AQ Directive, supra note 356, art. 23.

389. AQ Directive, supra note 356, art. 24.

390. AQ Directive, supra note 356, Annex XV B(3).

391. See, e.g., AEA, REPORT FOR THE EUROPEAN COMMISSION, SUPPORT TO THE IDENTIFICATION OF POTENTIAL RisKS For tHe ENVIRONMENT AND HuMan HEALTH ARISING FROM HYDROCARBONS OPERATIONS INVOLVING FRACTURING IN EUROPE iii-xVi, 105 (2012), archived at http://perma.cc/733G-6QGQ.

392. Id. at 30-32.

393. Id. at 97 .

394. Id. at 98. 
While various directives potentially apply to the impact on land, ${ }^{395}$ most of the activities relating to land use are covered under the Environmental Impact Assessment Directive. ${ }^{396}$ The EIA Directive covers the direct and indirect effects on fauna, flora, soil, and the landscape. ${ }^{397}$ Prior to the issuance of any mining permit, a well developer must provide the competent national authority with information on the expected impact on land as it relates to the construction and operation of the well. ${ }^{398}$

The Environmental Liability Directive ${ }^{399}$ may also be relevant for shale gas fracturing. The directive only applies to environmental damages caused by the operator through negligence or fault of her own, ${ }^{400}$ so it may not sufficiently address the environmental concerns associated with fracturing. ${ }^{401}$ But damage resulting from leakage in waste facilities or well blowouts could be covered. ${ }^{402}$ In addition, under the Habitats and Birds Directive ${ }^{403}$ damages to and impacts on protected species and natural habitats may also be covered.

\section{B. Current European Union Initiatives and Actions}

Hydrocarbon exploration of unconventional gas, such as shale gas, did not become a topic in the European Union until $2011{ }^{404}$ In February 2011, the European Union Heads of State and Government concluded that in order to "enhance its security of [the European energy] supply, Europe's potential for sustainable extraction and . . . conventional and unconventional (shale gas and oil shale) fossil fuel resources should be assessed. ${ }^{, 405}$

395. See, e.g., EIA Directive 2011/92, supra note 274; Council Directive 2001/42, supra note 274; Council Directive 2004/35, supra note 274; Council Directive 92/43, supra note 274; Council Directive 2009/147, supra note 274; Council Directive 1994/22, supra note 274.

396. Council Directive 2011/92, 2011 O.J. (L 26) 1 (EU).

397. Id. art. 3.

398. Id. art. 5(1) [5(1) references Annex IV].

399. Council Directive 2004/35/CE, supra note 274.

400. See Council Directive 2004/35/CE, supra note 274, art. 3(1)(b).

401. See, e.g., AEA REPORT POTENTIAL RISKS, supra note 13, at 99.

402. Council Directive 2004/35/CE, supra note 274, at Annex III.

403. Council Directive 2009/147/EC, supra note 274, art. 5; Directive 92/43/EEC, supra note 274, art. 16; Commission Annex to the Communication From the Commission to the European Parliament, the Council, the European Economic and Social Committee and the Committee of the Regions, COM (2012) 629 final (Oct. 23, 2012), archived at http://perma.cc/D4GJ-HXND.

404. Presidency Conclusions, Brussels European Court Council (EC) No. 2/11 Feb. 4, 2011, 3 ๆ 7, 2011 (O.J.), archived at http://perma.cc/EAUS-YXNF.

405. Id (alterations added). 


\section{The European Commission}

Following the 2011 mandate by the European Council, ${ }^{406}$ the Commission authorized its first independent study on shale gas exploration in some of the EU Member States. ${ }^{407}$ The study focused on the legal framework of shale gas exploration in Poland, Germany, France, and Sweden ${ }^{408}$ and concluded that the current European Union regulatory framework may not be sufficient for commercial scale exploration of shale gas in Western Europe. ${ }^{409}$ It also suggested that the EU regulatory framework may need to be assessed further, especially when considering the potential cumulative impacts of commercial shale gas exploration. ${ }^{410}$

Since the initial study, the Commission has released three additional external studies on shale gas exploration in Europe, raising further questions about the adequacy of the regulatory framework in the European Union. ${ }^{411}$ In response to these findings, the Commission included a new initiative in its 2013 Work Program on unconventional hydrocarbon extraction. ${ }^{412}$ The goal of this initiative is to analyze whether it may be necessary "to adapt European Union law to the specificities of unconventional fossil fuel projects and in particular shale gas. ${ }^{, 413}$ The Commission plans to finalize this initiative by the end of 2013. The initiative has two main objectives: ${ }^{414}$ (1) to ensure that all of the environmental risks linked to hydraulic fracturing are identified and managed appropriately, ${ }^{415}$ and (2) to establish a common approach across

406. Id.

407. Philippe \& Partners, Final Report on Unconventional gas in Europe 5 (2011), archived at $\mathrm{http}: / /$ perma.cc/U6C4-H5FP.

408. Id.

409. Id. at 102 .

410. Id. The report noted that "[e]specially, related potential cumulative impacts need to be further investigated to provide a basis for a more thorough assessment of the appropriateness of the regulatory framework(s) - both on EU as well as on Member State and/or regional level." Id.

411. Press Release, Eur. Comm'n, News from the Eur. Comm'n's Midday Briefing (Sept. 7, 2012), archived at http://perma.cc/BLT9-ZZYQ; see AEA REPORT POTENTIAL RISKS, supra note 13; Foster, supra note 29; JRC Research Study, supra note 29.

412. See, e.g., Annex to the Communication from the Commission to the European Parliament, the Council, the European Economic and Social Committee and the Committee of the Regions, COM (2012) 629 final (Oct. 23, 2012), archived at http://perma.cc/36PTTEY9.

413. Eur. COMm'N, ENVTL. Assessment Framework to Enable a Safe and SeCure UNCONVENTIONAL HYDROCARBON (E.G. SHALE GAS) EXTRACTION 2 (2012), archived at http://perma.cc/S83P-LSYB.

414. Id. at 2; see also, Eur. Comm'n, Presentation of the Results of the Public Consultation "Unconventional Fossil Fuels (e.g. Shale Gas) in Europe," ENVIRONMENT (June 7, 2013) [hereinafter "Eur. Comm'n"], archived at http://perma.cc/AXP5-WAY6.

415. Eur. Comm'n, supra note 414, at 2. 
the European Union by providing legislative "clarity, coherence and stability to market operators who wish to invest in unconventional hydrocarbons developments.",416

The Commission conducted a consultation of stakeholders ${ }^{417}$ and organized a first stakeholder meeting in June $2013{ }^{418}$ The result of the consultation included 22,875 responses, 94 percent of which were submitted by individuals and less than 6 percent of which were submitted by companies, lobbying groups or other organizations. ${ }^{419}$ The majority of respondents came from Poland, France, Romania, Spain, and Germany. ${ }^{420}$ Poland alone submitted more than 50 percent of the total number of responses, followed by France and Romania with approximately 14 percent and 13 percent, respectively. ${ }^{421}$ The majority of all respondents agreed that current European Union and Member State legislation is insufficient, more public information is needed, and that the public generally does not support the unconventional exploration and production of fossil fuels. ${ }^{422}$

\section{The European Parliament}

In November 2012, the European Parliament followed the Commission's initiative with a report on the environmental impact of shale gas and shale oil extraction activities in the European Union. ${ }^{43}$ The Parliament concluded that effective implementation of the European Union legislative framework is essential to ensure a proper evaluation of the risks associated with hydraulic fracturing. ${ }^{424}$ It called for a continuing analysis of the applicable regulatory framework and the completion of further studies on the potential environmental impacts of fracking. ${ }^{425}$ Among other things,

416. Eur. Comm'n, Presentation of the Results of the Public Consultation "Unconventional Fossil Fuels (e.g. Shale Gas) in Europe," ENVIRONMENT (June 7, 2013), archived at http://perma.cc/AXP5-WAY6.

417. Id.

418. Eur. Comm'n, Stakeholders Event on Unconventional Fossil Fuels (e.g. Shale Gas): Detailed Agenda (2013), archived at http://perma.cc/3JGR-96UX.

419. Eur. Comm'n, Presentation of the Results of the Public Consultation "Unconventional Fossil Fuels (e.g. Shale Gas) in Europe," ENVIRONMENT 3 (June 7, 2013), archived at http://perma.cc/AXP5-WAY6.

420. Id.

421. Id.

422. Id. at 6; for a more complete discussion of the results of the consultation, see Eur. Comm'n, Presentation of the Results of the Public Consultation "Unconventional Fossil Fuels (e.g. Shale Gas) in Europe," ENVIRONMENT (June 7, 2013), available at http://webcast.ec. europa.eu/eutv/portal/env/_v_fl_300_en/player/index_player.html?id=19800\&pId=19798.

423. See generally Resolution on the Environmental Impacts of Shale Gas and Shale Oil Extraction Activities, PARL. EUR. DOC. A7-0283/2012 If 2 (2012), archived at http://perma.cc/NJS7-RGRD.

424. See id. at $173,21$.

425. $I d$. at $\uparrow 60$. 
the Parliament singled out the shortcomings of the Environmental Liability Directive. ${ }^{426}$ It noted that the Directive did not obligate operators to carry adequate insurance associated with potential accidents in the extracting industry and suggested including such a mandate for hydraulic fracturing operators. ${ }^{427}$ In addition, the European Parliament called for a blanket ban on fracking in sensitive areas, such as areas where drinking water is present, ${ }^{428}$ and proposed that the industry not only be required to disclose the chemical composition of all hydraulic fracturing fluids, ${ }^{429}$ but that these fluids also be explicitly declared hazardous waste under the European Waste Directive. ${ }^{430}$

Most recently, on October 9, 2013, the European Parliament voted to revise the European Impact Assessment Directive and proposed various amendments to the Commission proposal. ${ }^{431}$ The Parliament's proposed amendments include a provision that would make any hydraulic fracturing activity, regardless of size, subject to a mandatory environmental impact assessment in Europe. ${ }^{432}$ Under the co-decision procedure, the European Parliament proposal will now be renegotiated between the Parliament and the Council before it can be adopted as a binding European Union directive. ${ }^{433}$

\section{CONCLUSION}

The European Union has not experienced a shale gas revolution comparable to that of the United States. In fact, no commercial scale exploration of shale gas has been established to date anywhere in Europe. Similarly, the existing regulatory framework that applies to hydraulic fracturing in the European Union is ineffective and fragmented at best.

426. See, e.g., id. at preamble recital $O$.

427. Id. at preamble recital $\mathrm{O}$, I 14; the EP also called for the reversal of the burden of proof for shale gas operators. Id. at $\{27$; further, the EP stated that mutual non-disclosure agreements regarding any damage to the environment would violate EU law. Id. at 117.

428. Id. at $\uparrow 34$.

429. Id. at 941 .

430. Id. at 928.

431. See, e.g., Press Release, European Parliament, Commissioner Janez Potočnik Welcomes the European Parliaments Vote on the New Environmental Impact Assessment Directive (Oct. 9, 2013) (stating "I welcome the outcome of today's vote on the Commission proposal .... We will now carefully examining the proposed amendments."), archived at http://perma.cc/39WL-KKBY.

432. See, e.g., Amendments Adopted by the European Parliament on 9 October 2013 on the Proposal for a Directive of the European Parliament and of the Council Amending Directive 2011/92/EU of the Assessment of the Effects of Certain Public and Private Projects on the Environment, COM (2012) 628 final (Oct. 9, 2013), archived at http://perma.cc/7JE5-SZV2.

433. See, e.g., Press Release, European Parliament, Shale Gas: New Fracturing Projects Must Pass Environmental Test (Oct. 9, 2013), archived at http://perma.cc/ZD9X-CFHH. 
Currently none of the applicable EU regulations and directives mention hydraulic fracturing. Moreover, EU Member States often retain a significant amount of discretion with respect to these rules and the issuance of shale gas exploration permits. This not only results in regulatory uncertainty for the industry, but may also set the stage for a race to the bottom in terms of environmental protection in the European Union, particularly if Member States start competing to attract the necessary investments for commercial shale gas exploration.

Thus far, the European Union has failed to set any minimum protective standards for fracking. A grant of primacy with effective Unionwide oversight, similar to that in the United States, does not exist under European Union law. It is then no surprise that Europe is looking toward the United States as a potential model for its nascent regulatory framework. But despite its long experience with shale gas exploration and production, the United States also lacks a comprehensive umbrella statute dealing with fracking. While many unsuccessful attempts have been made to pass such legislation in the United States, today at least eight federal environmental and public health statutes regulate most aspects of shale gas exploration, development and production. Still, many exemptions exist for the fracking industry under these statutes, perhaps most notably, Congress' exemption of fracking under the Safe Drinking Water Act. ${ }^{434}$

It is clear that with intensifying commercial exploration of shale gas in the United States, environmental and health concerns have also significantly increased. As a result, the effectiveness of the US regulatory framework for fracking is being questioned to the same extent as in the European Union. The EPA, for example, has begun to conduct studies to further examine the impact of shale gas exploration on drinking water. Results are forthcoming, leaving uncertainty as to what, if any, changes to regulatory authority will follow. With these regulatory shortcomings, it is questionable whether the current regulatory framework in the US can truly act as a model for the European Union. To be sure, the EU can and should rely on certain aspects of the US experience, but the EU must also move beyond developments in the US and has already taken steps to do so. For example, mutual non-disclosure agreements regarding damages to the environment and human health may not be allowed in the EU and all hydraulic fracturing activities may become subject to a mandatory environmental impact assessment. Gaps in regulatory authority and the lack of a comprehensive framework that encompasses all aspects and impacts of shale gas production would only hinder the ability to address future challenges. And so, with no clear regulatory framework in place, the EU may be in a better position than the US to address the environmental and health concerns of fracking in a more comprehensive, less piecemeal, 
manner. Ultimately, only such an approach will ensure that all environmental risks linked to fracking are identified and managed appropriately in the EU. 